\title{
HİTIT KRALLIĞI’NDA KENT VE ÜLKE SAVUNMASI
}

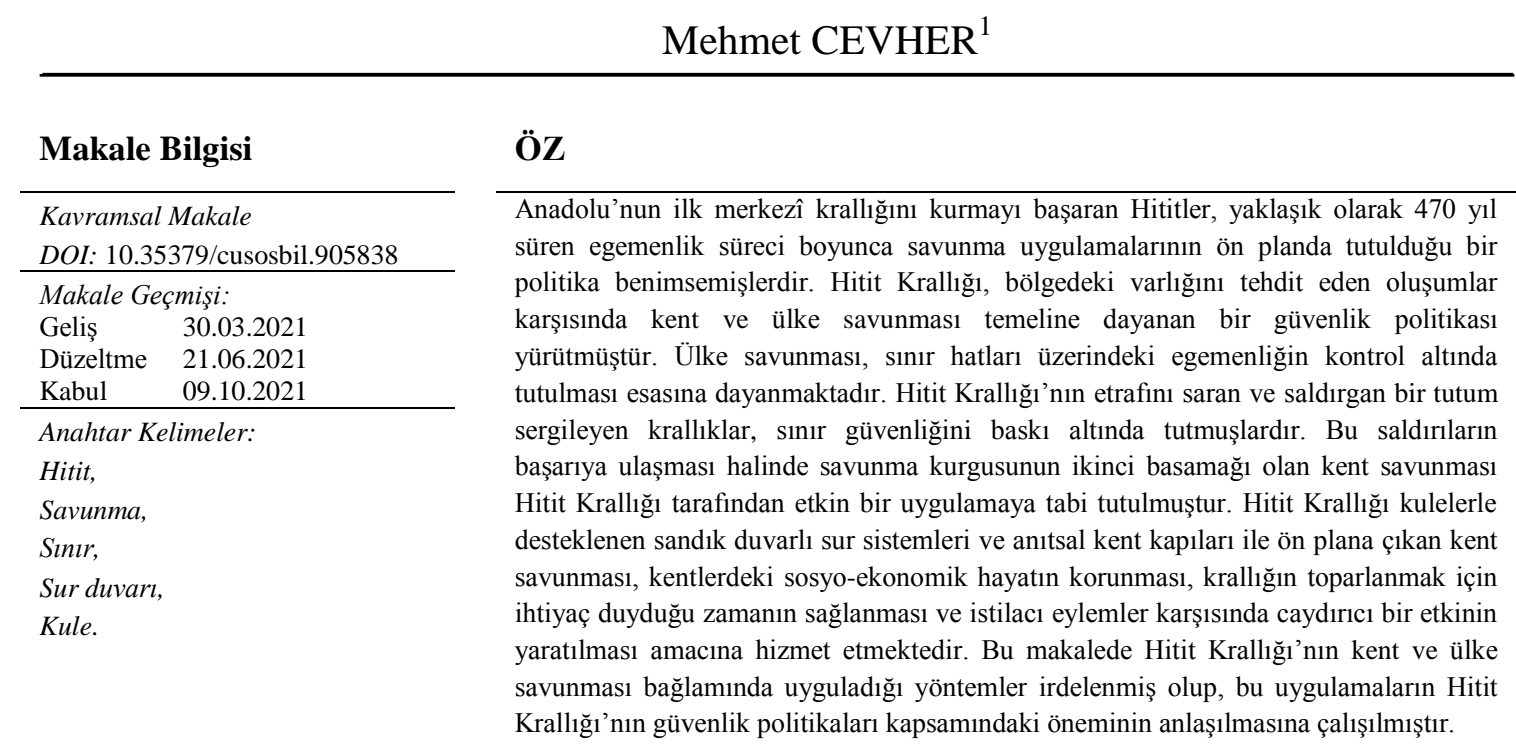

\section{CITY AND COUNTRY DEFENCE IN THE HITTITE KINGDOM}

\begin{tabular}{l} 
Article Info \\
\hline Conceptual Article \\
DOI: $10.35379 /$ cusosbil.905838 \\
\hline Article History: \\
Received $\quad 30.03 .2021$ \\
Revised $\quad 21.06 .2021$ \\
Accepted $\quad 09.10 .2021$ \\
\hline Keywords: \\
Hittite, \\
Defence, \\
Border, \\
City wall, \\
Tower.
\end{tabular}

\footnotetext{
${ }^{1}$ Dr., Çukurova Üniversitesi, Fen Edebiyat Fakültesi, Arkeoloji Bölümü, mcevher@cu.edu.tr, ORCID: 0000-0001-9767-8747. Alıntılamak için/Cite as: Cevher, M. (2021), Hitit Krallığı'nda Kent ve Ülke Savunması, Çukurova Üniversitesi Sosyal Bilimler Enstitüsü Dergisi, 30 (2), 28-46.
}

\begin{abstract}
The Hittites, who succeeded in establishing the first central kingdom of Anatolia adopted a policy that prioritized defense practices during the period of rule that lasted approximately 470 years. The Hittite Kingdom carried out a security policy based on the defense of the city and the country against the formations that threatened its existence in the region. The country's defence is based on the principle of controlling sovereignty over border lines. The kingdoms that surrounded the Hittite Kingdom and displayed an aggressive attitude put the border security under pressure. If these attacks were successful, the defense of the city as the second step of the defense set up was effectively practiced by the Hittite Kingdom. The city defense standing out with casemate fortification systems and monumental city gates supported by towers serves the purpose of protecting the socio-economic life in the cities providing the time needed by the kingdom to recover and creating a dissuasive effect against invasive actions. In this paper, the methods used by the Hittite Kingdom in the context of city defense and country defense were examined and the importance of these practices in the security policies was tried to be understood.
\end{abstract}




\section{GIRISS}

MÖ. 17. yy. ortalarında Kızılırmak kavsi içinde kurulan Hitit Krallığı, Anadolu'daki parçalı siyasi yapıdan faydalanarak kısa süre içinde genişleme imkânı elde etmiş ve yürüttüğü başarılı operasyonlar sayesinde çekirdek ülkenin ötesine uzanan sınırlara sahip olmayı başarmıştır. Anadolu'daki uzun soluklu Hitit egemenliği boyunca savaşlar, isyanlar, sınır ihlalleri yaygın bir güvenlik sorunu olarak varlığını uzun süre korumuştur. Ortaya çıkan bu güvenlik sorunu karşısında Hitit Krallığı, ülke ve kent savunması temeline dayanan politikalar aracıllı̆̆ ile bölgedeki egemenliğini koruma altına almaya çalışıştır. Ele alınan konunun ilk bölümünde ülke savunması başlığ altında incelenen tampon bölgeler, sınır komutanları ve nüfus aktarımları ile ilgili olarak Hitit yazılı metinlerinden yararlanılmıştır. Yazılı metinler üzerinde yapılan incelemelerde ülke savunmasının kırılgan bir yapıya sahip olduğu görülürken, III. Tuthaliya'nın iktidarı sırasında meydana gelen ve Hitit Ülkesi'nin dört bir yandan işgal altında kaldığından bahsedilen metinde bu durum açık bir şekilde izlenebilmektedir (CTH 88, Bryce, 2005, s. 146).

Güvenlik uygulamalarının ikinci ayağı olan kent savunması, Hitit yerleşim merkezlerinde yürütülen kazı çalışmaları ile net olarak ortaya konmuştur. Hitit merkezlerinde açığa çıkarılan sur duvarları, kuleler, bastiyonlar, yığma setler ve kent kapıları savunma mimarisinin anlaşılmasına yardımcı olmuştur. Kazı çalışmalarında açığa çıkarılan mimari düzenlemelere ek olarak Hitit Krallı̆̆ı'ndaki kent savunmasının önemine dair aydınlatıcı bilgiler içeren yazılı metinlerden de yararlanılmıştır. Hitit metinlerde, krallar tarafından tahkim edilen kentlerden ve (CTH 11; de Martino, 2003, s. 191-192, 198-200; KBo 5.6; Ertem, 1980, s. 51-55; Ünal, 2018, s. 557) "HAZANNU" adı verilen yöneticiler tarafından giriş kapılarının her akşam mühürlenerek kontrol altında tutulduğundan bahsedilmektedir (CTH 257/1; Miller, 2013, s. 183-185). Bir başka metinde ise Hitit kralı tarafından sınır boylarındaki yöneticilere gönderilen talimatnamede sur duvarı ile ilgili gerekli bakımların yapılmasını içeren bilgiler (CTH 261.I; Miller, s. 213) Hitit Krallığı’ndaki kent savunmasının önemine ışık tutmaktadır.

\section{Hititler'de Ülke Savunması}

Hitit Krallığı'nda savunma zincirinin ilk halkası, ülke savunması kapsamında icra edilen politikalardan meydana gelmektedir. Ülke güvenliğinin korunmasına yönelik uygulanan yöntemler arasında yer alan tampon bölgeler, düşman krallıklar tarafindan gerçekleştirilen saldırılar karşısında anayurdu koruma altına alan birer ön savunma hattı vazifesi taşımaktadır. Hitit Krallığı, Kızılırmak kavsi içinde yer alan anayurdunu korumak amacıyla krallı̆̆ın kuzey, doğu, güney ve batı bölgelerinde tampon bölgeler oluşturmuştur. Tampon bölgeler dışında Hitit metinlerinde karşımıza çıkan ve sınır komutanı olarak tanımlanan 'Bel Madgalti' 'ler ise sınır hatlarındaki istikrarın korunması konusunda geniş yetkiler taşımıştır. Hitit kralları önderliğinde başarı ile yürütülen seferler sonrasında hayata geçirilen nüfus aktarımları da ülke savunması ile ilgili uygulanan yöntemler arasında yer almaktadır.

\subsection{Tampon Bölgeler}

Hitit Krallığı'nda sınır güvenliğinin sağlanmasının ilk adımı olan tampon bölgeler, oldukça sık kullanılan bir uygulama olarak karşımıza çıkmaktadır (Bryce, 1986, s. 87-98). Hitit Krallığı, etrafını saran düşman krallıklar ile uzun süre mücadele etmek zorunda kalmıştır. Krallığın kuzeyinde yer alan Kaškalar, yıkılışa kadar devam eden dönem boyunca gerçekleştirdikleri akınlar ile bölgedeki Hitit otoritesinin zayıflamasına neden olmuştur. Kuzeydeki Kaška kabileleri dışında Kuzeydoğudaki Azzi-Hayaša Krallığı, doğu ve güneydoğudaki HurriMitanni Krallığı ile batıdaki Arzawa Krallığı'nın saldırgan tutumları ülke güvenliği açısından tehdit oluşturan diğer unsurlar olarak karşımıza çıkmaktadır. Hititler, sınır boylarında yaşanan saldırgan eylemler karşısında anayurt ile düşman krallıklar arasında tampon bölgeler yerleştirerek sınır hatlarındaki egemenliğini koruma altına almaya özen göstermiş̧tir (Şekil 1). Kuzeydeki Kaška toplulukları ve kuzeydoğudaki Azzi-Hayaša Krallığı'nın baskınları karşısında Tokat, Sivas ve Amasya illerini kapsayan coğrafi sınırlar içinde yer aldığı düşünülen (Alparslan, 2017, s. 177; Dönmez, 2017, s. 80) Yukarı Ülke, saldırıların göğüslendiği ilk savunma hattı olarak kullanım görmüştür (Gurney, 2003, s. 121).

Hitit Krallığı'nda Yukarı Ülke'nin varlı̆ğna ilk olarak III. Tuthaliya Dönemi'nde rastlanmaktadır. III. Tuthaliya'nın iktidarı sırasında bu bölgede yer alan Maşat Höyük/Tapikka'nın Kaška saldırıları karşısında bir garnizon kenti olarak kullanıldığı anlaşılmaktadır (Özgüç, 2002; Mielke, 2011a, s. 1047). Yukarı Ülke sınırları içinde bulunan ve son çalışmalar ile birlikte Sivas'ın Yıldızeli ilçesindeki Kayalıpınar Höyüğü ile eşitlenen Šamuha, Yukarı Ülke'nin kült ve yönetim merkezî olup, (Müller-Karpe \& Müller-Karpe, 2016, s. 297) I. Šuppiluliuma Dönemi’nde Azzi-Hayaša saldırıları karşısında bir sınır karakolu vazifesi taşımıştır (Garstang \& 
Gurney, 1959, s. 33). II. Muwatalli Dönemi’nde Yukarı Ülke'nin idaresinden sorumlu olan III. Hattušili bölge üzerindeki nüfuzunu arttırarak Yukarı Ülke’yi krallık gibi yönetmeye başlamıştır. Bu süreçte Amasya'da aranması gerektiği önerilen Hakmiš, Hitit Krallı̆̆ı'nın güvenlik ve yönetim politikaları çerçevesinde ön plana çıkmıştır (Murat, 2008, s. 202).

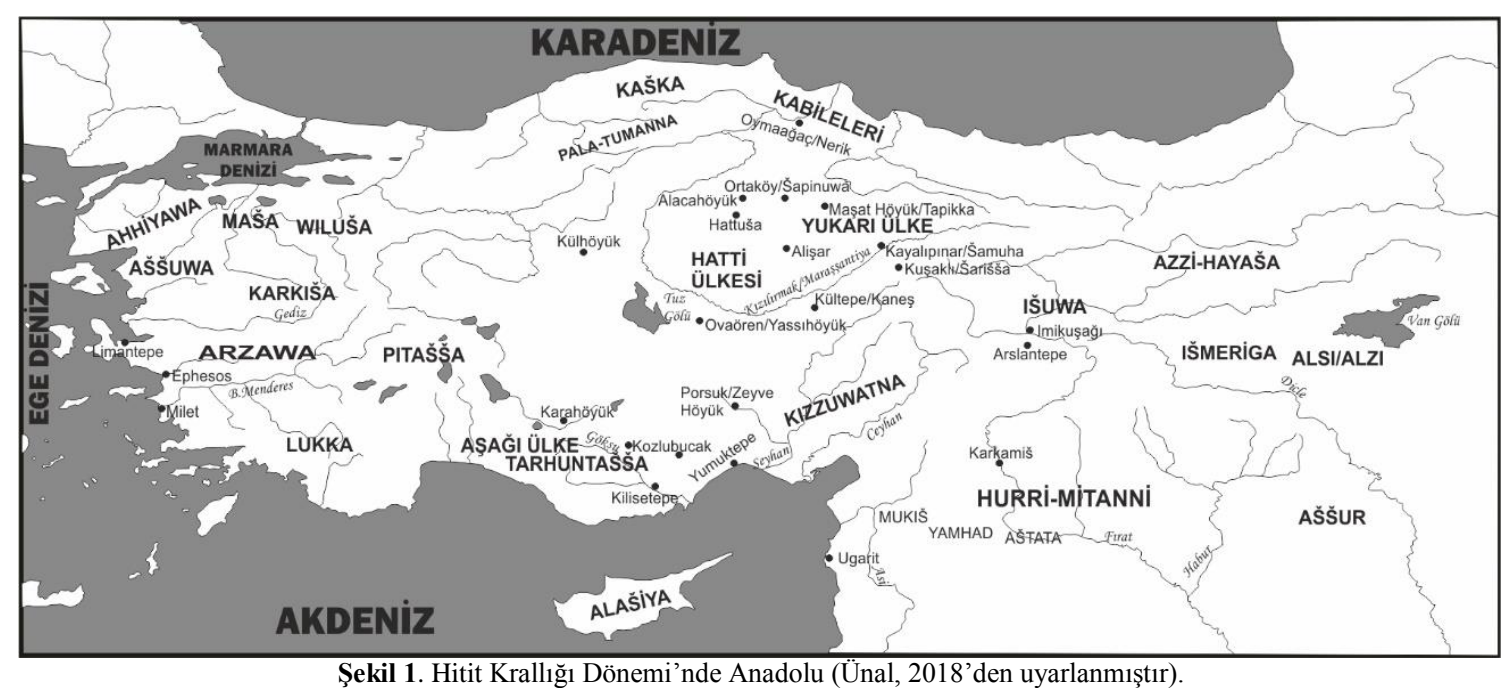

Hitit Krallığı'nın doğusunda yer alan Išuwa Krallığı, Hurri yayılımı karşısında doğu sınırını korumaktadır. Išuwa Krallığı'nın, Elazığ-Malatya illerini kapsayan sınırlar etrafında hüküm sürdüğü öne sürülmektedir (Manuelli, 2017, s. 138). Hititler, ekonomi ve güvenlik politikalarının devamlılığı noktasında Išuwa üzerinde Hitit hâkimiyetinin kurulmasına önem vermiş olup bu yaklaşıma dair en etkili girişimler I/II. Tuthaliya ve I. Šuppiluliuma'nın iktidarı sırasında hayata geçirilmiştir (Gurney, 2003, s. 123). I. Šuppiluliuma, Išuwa üzerine gerçekleştirdiği askerî seferler sayesinde Išuwa'yı Hitit boyunduruğu altına almayı başarmıştır. Išuwa, üzerinde Hitit hâkimiyetinin egemen kılınması ile birlikte doğu sınırı düzene kavuşmuş olup K. Suriye'ye ulaşım sağlayan güzergâhların denetimi de Hitit Krallığı'nın eline geçmiştir (Bryce, 1986, s. 94).

Hitit Krallığı'nın güney cephesinde yer alan Kizzuwatna Krallığı, Hurri-Mitanni Krallığı ile Hitit Krallığı arasında bir tampon bölge niteliği taşımaktadır (Sir Gavaz, 2008, s. 30-31). Kizzuwatna'nın günümüzde Çukurova, antik dönemde ise Kilikya olarak bilinen coğrafi sınırlar içinde yer aldığı kabul edilmektedir (Ünal, 2006, s. 17). Güneydeki Hurri-Mitanni yayılımı karşısında bir koruma hattı oluşturan Kizzuwatna'nın aynı zamanda K.Suriye'ye ulaşım sağlayan güzergâhlar bakımından jeopolitik öneme sahip olduğu bilinmektedir (Seton-Williams, 1954, s. 125; Ünal, 2006, s. 17, 24). Hurri-Mitanni Krallığ i ile yakın ilişki içindeki Kizzuwatna'nın, Hitit Krallığı'na bağlanması oldukça uzun süre devam eden diplomatik girişimler sonrasında mümkün olabilmiştir. Eski Hitit Dönemi'nden beri dostane temellere dayanan bu ilişkiler sonucunda Kizzuwatna Krallığı, Hurri-Mitanni Krallığı'nın egemenlik sahasından koparılarak Hitit Krallığı'na bağlanmıştır. Kizzuwatna üzerinde kurulan egemenlik süreci ile birlikte güney’deki Hurri-Mitanni akınları dizginlenmiş ve K.Suriye'deki Hitit çıkarları da güvence altına alınmıştır (Sir Gavaz, 2008, s. 30-31).

Hitit Krallığı'nın kuzey sınırında olduğu gibi batı sınırında da istikrarsız bir tablo ile karşılaşılmaktadır. Batıda yer alan Arzawa Krallığı'nın Hitit karşıtı politikaları desteklemesi ve Hitit vasalı haline gelen krallıklar arasında yaşanan çıkar çatışmaları, sınır hattında sorunlu bir yapının ortaya çıkmasına neden olmuştur (Macqueen, 2009, s. 60). Hititler, Batı Anadolu'daki bu sorunlu yapı karşısında, Konya Ovası'nın Tuz Gölü'nü kapsayan uzantısı ile güneyde Toros Dağları tarafından sınırlandırılan alan içinde yer alan Aşağı Ülke'yi tampon bölge olarak kullanmıştır (Ertem, 1980, s. 15).

Aşağı Ülke, Arzawa saldırılarını engellemek dışında aynı zamanda Batı Anadolu'ya karşı yapılacak seferler sırasında da Hitit ordusu tarafından karargâh merkezî olarak kullanım görmüştür. Aşağı Ülke sınırları içinde bulunan; ancak lokalizasyonu konusunda fikir birliği sağlanamayan Šallapa'nın² Arzawa Krallığı'na ulaşım sağlayan güzergâh hattı üzerinde yer aldığı ve Batı Anadolu eksenli yürütülen seferler sırasında harekât merkezî

2 Šallapa'nın lokalizasyonu ile ilgili tartışmalar için bkz. (Kryszeǹ, 2012). 
olarak kullanıldığı anlaşılmaktadır. Nitekim II. Muršili'nin, Arzawa'ya düzenlenen operasyon sırasında Kargamış Kralı Šarrikušuh'un (Piyaššili) getirdiği askerî destek ile Šallapa'da buluşması (KBo 3.4; Ünal, 2018, s. 626; Bryce, 2005, s. 194) ve III. Hattušili'nin Batı Anadolu'da Hitit çıkarları aleyhine hareket eden Piyamaradu'nun kendisine teslim edilmesi için Šallapa'da konaklaması, söz konusu kentin karargah merkezî işlevi gördüğünü desteklemektedir (CTH 181; Beckman, vd. 2011, s. 103).

Tampon bölgeler Hitit sınır güvenliğinin korunmasına yardımcı olurken bu bölgelerde yer alan ve stratejik öneme sahip geçitler ülke güvenliği kapsamında ön plana çıkmaktadır. Išuwa Krallığı, Fırat Irmağı'nın aşılmasına imkân tanıyan bir coğrafya içinde yer almaktadır. Yukarı Fırat Havzası'nda yer alan İmikuşağı (MÖ 1700-1600) (Sevin, 1995, s. 3; Konyar, 2006, s. 334-337) ile Arslantepe (MÖ 1750-1600) (Frangipane, 2011, s. 985; Manuelli, 2013, s. 417-422) tahkimli merkezler olup geçiş güzergâhı üzerindeki Hitit egemenliğinin korunmasina hizmet etmektedir.

Hitit Krallığı'nın, Akdeniz kıyılarına erişim sağlayan Gülek ve Sertavul geçitleri üzerinde de hareketliliğin kontrol altında tutulmasına önem verdiği görülmektedir. Gülek Boğazı'nın kuzey çıkışında, Niğde-Ulukışla civarında yer alan Porsuk Höyük, geçidi kontrol altında tutan bir konumda bulunmaktadır (Gates, 2011, s. 400; Beyer, 2006, s. 65). Batıdaki Sertavul geçidi üzerinde Kilisetepe yerleşmesi ön plana çıkmaktadır. Mersin, Mut ilçesinde bulunan Kilisetepe, Göksu Vadisi aracılığı ile Orta Anadolu'ya açılan geçidin ortasında yer alırken (Matessi \& Tomassini Pieri, 2017, s. 99; Gates, 2011, s. 401) bu güzergâhın kuzey ucunda yer alan Kozlubucak yerleşmesinin de Hitit İmparatorluk Çă̆ı'nda ulaşım ağının güvenliğinden sorumlu olduğu anlaşılmaktadır (Matessi \& Tomassini Pieri, 2017, s. 99). Hitit Krallı̆̆ı'nın bölgeler arası ulaşım ağı üzerinde kurduğu stratejik merkezlere anayurdu çevreleyen Kızılırmak Nehri üzerinde de rastlanmaktadır. Kızılırmak yatağının daraldığı alanlarda ortaya çıkan geçiş yolları tahkimli bir yapıya sahip olan Büklükale (Matsumura, 2013, s. 274) ve Kayalıpınar/Šamuha (Ökse, 2008, s. 366) yerleşmeleri aracılığı ile gözetim altında tutulmuştur.

\subsection{Sinır Komutanları (Bel Madgalti)}

Hitit Krallığı, sınır boylarında görevlendirdiği ve geniş yetkiler tanıdığı yöneticiler ile sınır hatları üzerindeki egemenliğini güçlendirmeye çalışmıştır. Hitit metinlerinde sınır bölgelerine atanan yöneticiler 'Bel Madgalti", adı ile tanınırken (Beal, 1992, s. 426-436; Bryce, 2003, s. 132) Bel Madgalti: Askerî vali, hudut beyi, sınır komutanı, nöbetçi kulesinin efendisi anlamına gelmektedir (Ünal, 2016, s. 97, 102, 329). Sınır komutanlarının üstlendiği görevlerden en önemlisi düşman hareketinin izlenmesi ile ilgilidir. Sınır boylarında meydana gelen hareketliliğin takip edilerek hızlı bir şekilde krala bildirilmesi, gerekli tedbirlerin alınmasını ve saldırgan girişimlerin başlamadan bastırılmasını kolaylaştırmaktadır. Gözetleme işlemi, bölgeyi devriyeler halinde tarama ve geçiş güzergâhlarının takip edilmesi şeklinde gerçekleştirilmektedir (Beal, 1992, s. 428-429; Miller, 2013, s. 212-213).

'Bel Madgalti' 'ler, genellikle Hitit Krallığı'nın kuzey sınırında görevlendirilmiştir. Tokat'ta bulunan Maşat Höyük/Tapikka'da ele geçen ve Hitit Kralı ile sınır komutanı arasında geçen yazışmalar bu düşünceyi doğrulamaktadır (MŞT 75/40; Hoffner, 2009, s. 100). Kuzey sınırında sonu gelmeyen Kaška saldırıları bölgedeki nüfus yoğunluğunun tenhalaşmasına neden olurken, bu alanlara atanan 'Bel Madgalti' ler sosyo-ekonomik hayatın devamlılığını sağlayarak Hitit Krallığı'nın bölge içindeki etkinliğini koruma görevini üstlenmişlerdir.

\subsection{Nüfus Aktarımları}

Nüfus aktarımları, isyancı toplulukların anayurtlarından koparılarak başka alanlara sürgün edilmesi esasına dayanmaktadır. Yakın Doğu krallıkları arasında sıklıkla kullanılan bir güvenlik politikası olan nüfus aktarımlarının (Oded, 1979) Hitit Krallığı tarafından da yaygın bir şekilde kullanıldığı anlaşılmaktadır. Nüfus aktarımları ile isyan eden kent halkının cezalandırılması, Hitit otoritesine boyun eğmeyen topluluklara gözdağı verilmesi ve potansiyel isyan riski taşıyan bölgelerin ıssızlaştırılarak demografik yapının Hitit çıkarlarına uygun olacak şekilde düzenlenmesi amaçlanmaktadır (Bryce, 2005, s. 217). Hitit Krallığı'nda nüfus aktarımları başarı ile sonuçlanan askerî seferler sonrasında hayata geçirilmektedir. Seferler sırasında ele geçen ve NAM.RA adı ile anılan topluluklar, anayurtlarından koparılarak Hitit Ülkesi'ne taşınan esirleri ifade etmektedir (Alp, 1949, s. 246; Hoffner, 2002, s. 61).

Hitit Krallı̆̆ı'nda uygulanan nüfus aktarımı ile ilgili ilk veriler I. Hattušili Dönemi'nde karşımıza çıkmaktadır. I. Hattušili Dönemi'nin icraatlarını konu alan yazılı metinde, Ulama kentinin Hitit otoritesine isyan ettiğginden ve başarı ile sonuçlanan kuşatma savaşı sonrasında isyana kalkışan kent halkının tamamının sürgün edilerek Ulama'nın yerleşime yasaklandığından bahsedilmektedir (KBo 10.1; Houwink ten Cate 1984, s. 48). Hitit Krallı I/II Tuthaliya Dönemi’nde nüfus aktarımlarının kitleler halinde uygulanmaya başladığı 


\section{Çukurova Üniversitesi Sosyal Bilimler Enstitüsü Dergisi, Cilt 30, Sayı 2, 2021, Sayfa 28-46}

görülmektedir. I/II Tuthaliya Dönemi'ne tarihlenen metinde Batı Anadolu'da geçekleştirilen nüfus aktarımları konu edilmiştir. Metinde Hitit karşııtı bir güç halini alan Aššuwa Konfederasyonu üzerine sefer düzenlendiği, devamında konfederasyon üyelerinin mağlup edildiği ve sayıları 10.000 kişiyi bulan Aššuwalı toplulukların Hitit Ülkesi'ne taşındığı bilgisine ulaşılmaktadır. (KUB 23.11; Garstanng \& Gurney, 1959, s. 122; Ünal, 2003, s. 13). II. Muršili Dönemi'nde Hitit Ülkesi'nde yaşanan veba salgını nüfus sayısının ciddi oranda azalmasına neden olmuştur. Bu dönemde Hitit Ülkesi’nde bozulan nüfus dengesini yeniden güçlendirmek amaciyla oldukça yoğun bir kullanıma sahne olmuştur. II. Muršili, Arzawa üzerine gerçekleştirdiği seferlerde, Arinnanda Dağı'ndan 15.000, Puranda'dan 15.500, Seha Nehri Ülkesi'nden ise 4000 kişiyi Hatti Ülkesi'ne taşımıştır. Başka alanlardan toplananlar ile beraber bu sayının 66.000'e çıktığı öne sürülmektedir (KBo 3.4; Mellaart, 1984, s. 218).

II. Muršili, Batı Anadolu dışında Kuzey Anadolu'da da nüfus aktarım politikasını etkili bir şekilde kullanmaya devam etmiştir. II. Muršili, Kaška bölgesinde gerçekleştirdiği işgallerde 1530 kişiden oluşan topluluğu Hitit Ülkesi’ne taşıyarak kuzeydeki Kaška nüfusunu zayıflatmaya çalışmıştır (Ertem, 1980, s. 87). II. Muršili iktidarının, 17. ve 20. yılları arasında gerçekleştiği düşünülen ve Kaška seferlerini konu alan bir diğer metinde ise ulaşılması güç bir coğrafyada yer alan Timmuhala'nın ele geçirildiğinden bahsedilmektedir (KUB 19.37; Ertem, 1980, s. 86-87). Hitit karşıtı politikalara destek vermesi ve coğrafi açıdan elde tutmanın zor olması sebebiyle Timmuhala, II. Muršili tarafından Fırtına Tanrısı'na adanarak yerleșime yasaklı kentler sınıfına dâhil edilmiştir (Bryce, 2003, s. 133). III. Hattušili Dönemi'nde de nüfus aktarımına dair önemli bilgilere ulaşılmaktadır. II. Murșili Dönemi'nde, Tiliura'da kısa süreliğine kurulan Hitit hâkimiyeti ile ilgili olarak III. Hattuşili, doğru bir şekilde uygulanmayan nüfus aktarımlarının söz konusu başarısızlı̆ı̆ın ortaya çıkmasında belirleyici olduğundan bahsetmektedir (CTH 89; Hoffner, 2002, s. 64). III. Hattuşili, Tiliura'yı ele geçirdikten sonra daha önceki uygulamalardan farklı olarak bu bölgenin yerlisi olan toplulukları Tiliura'ya yerleştirmek sureti ile bölgedeki Hitit hâkimiyetini kalıcı hâle getirmeye çalışmıştır (Bryce, 1986, s. 91-92). Hitit Krallığı'nın son yıllarında, II. Šuppiluliuma Dönemi’nde Batı Anadolu ve Tarhuntašša üzerine gerçekleştirilen seferler sırasında nüfus aktarımları kullanılmaya devam edilmiştir. Tarhuntašša'ya düzenlenen operasyon sırasında ele geçirilen topluluklar, bulundukları bölgeden sürgün edilerek Hitit egemenliği altındaki Tana kentine yerleştirmiştir (CTH 215; Hawkins, 1995, s. 22-23).

Hititler, ülke sınırlarını farklı yaklaşımlarla korumaya çalışmışlardır. Problemli olan sınır noktalarında düşman grup ya da devletlerle teması yumuşatacak tampon bölgeler oluşturmuşlardır. Ülke sınıllarına yakın noktalardaki yerleşimlerin yönetimini kendilerine sıkıca bağlı yerel yöneticiler aracılı̆̆ ile gerçekleştirmişlerdir. $\mathrm{Bu}$ süreçteki önemli adımlardan biri ise nüfus aktarımlarıdır. Sıkıntılı olabilecek bölgelerde ya da sıkıntı oluşturabilecek gruplar içinde demografik yapı doğrudan müdahaleler ile bilinçli olarak değiştirilmiş̧ir. Bu yönü ile ülke sınırları kontrol altına alınmaya çalışılmıştır. Hititlerde bütüncül savunma kurgusunun ikinci ayağı mimari düzenlemelerin ön plana çıktığı kent savunmasından oluşmaktadır.

\section{Hitit Krallığı'nda Kent Savunması}

Hitit Krallı̆̆ı'nın Anadolu'daki egemenliği ile beraber kent savunması daha önceki dönemlerden farklılaşarak standart bir görünüm sergilemeye başlamıştır. Savunma mimarisindeki standartlaşma, Hitit kentlerinde açığa çıkarılan ve yaygın bir kullanıma sahne olan sandık duvarlı surlar, kule yapıları ve kent kapıları üzerinde izlenebilmektedir. Yığma toprak setler kent savunmasına yardımcı olan diğer unsurlar arasında yer alırken, sur duvarı altında bulunan potern yapılarının askerî işlevi ile ilgili tartışmalar günümüzde de devam etmektedir.

\subsection{Sur Duvarları}

Hitit kentlerini koruma altına alan sur duvarları plan ve işlevsel özellikleri bağlamında, masif, testere dişli, kazematlı ve sandık duvarlı sur olmak üzere dört grup altında incelenmiştir. Anadolu'da MÖ II. binyıldan önce sıklıkla kullanılmış olan masif karakterli sur duvarları, Orta Kalkolitik Dönem'de Güvercinkayası (Gülçur, 2012, s. 218-220), Erken Tunç Çağı I'de Limantepe (Erkanal \& Şahoğlu, 2016, s. 158) ve Erken Tunç Çăğ II'de Kinet Höyük (Gates, 2009, s. 354) merkezlerinde karșımıza çıkarken söz konusu sur duvarlarına Hitit savunma mimarisinde de rastlanmaktadır. Boğazköy/Hattuša'daki Büyükkale'de ve Yukarı Şehir'de masif sur kullanımına dair verilere ulaşılmıştır. Büyükkale'nin kuzey ve doğu yamaçlarındaki topoğrafyasının savunma açısından elverişli koşullara sahip olması sebebi ile bu alanlardaki sur duvarı güneydeki sandık duvarlı surdan farklı olarak masif bir yapıda inşa edilmiştir (Mielke, 2018, s. 69). Boğazköy/Hattuša'nın Yukarı Şehir kesiminde açığa çıkarılan diğer masif sur MÖ 13. yy.'nn ikinci yarısına tarihlendirilmektedir (Schachner, 2010, s. 665, dnt. 20) (Şekil 2). Bu koruma duvarı MÖ 16. yy. sonu, 15. yy. başında inşa edildiği önerilen sandık duvarlı sur hattının 8 
m. önünde yer almaktadır (Mielke, 2018, s. 70). Yerkapı rampasındaki kaplama taşların sökülerek sur duvarı üzerinde kullanıldığı ve Yerkapı rampasına ulaşım sağlayan merdivenlerin ön surun inşası sürecinde işlevini yitirdiği görülmektedir. Yukarı Şehir'deki masif surun inşası ile birlikte kademli bir savunma hattı elde edilerek bu alandaki savunma mimarisinin güçlendirildiği ve gerçekleşmesi beklenen istila eylemi karşısında krallığın teyakkuz hali içinde olduğu anlaşılmaktadır (Schachner, 2019, s. 26; Nossov, 2008, s. 29).

Hitit savunma mimarisinde kullanımı sınırlı olan testere dişli surlar, duvar hattının kademeli bir şekilde öne ve arkaya doğru çekilmesi ile inşa edilmektedir. Sur hattında ortaya çıkan ve testere dişine benzeyen çıkıntılar sebebiyle bu yapılar testere dişli sur duvarı olarak adlandırılmıştır (Vincenzi, 2008). Sur duvarları genellikle yerleşim yerine alan kazandırmak için yamaçlara yakın alanlar üzerinde inşa edilmektedir. Sur duvarının yamaçlara inşa edilmesi sonucunda duvarın mukavemeti noktasında yaşanan zafiyet sur hattının kademeli bir şekilde inşa edilmesi ile bertaraf edilmektedir (Naumann, 2007, s. 249). Testere dişli surlarda, yarım bastiyon olarak tanımlanan çıkıntılar sayesinde sur diplerinin kontrol altında tutulmasını sağlayan etkili bir atış hattı elde edilmiştir (Keeley vd. 2007, s. 77; Kern, 1999, s. 11-12). Hitit Krallı̆̆ı'nda testere dişli sur mimarisi, Tatarlı Höyük, (Girginer vd. 2014, s. 184; Cevher, 2020, s. 66), İmikuşağı (Konyar, 2006, s. 334-337) dişında testere dişli ve sandık duvarlı sur mimarisinin bir arada görüldüğü Mersin-Yumuktepe'de (Garstang, 1953, s. 236-237. fig. 151; Jean, 2006, s. 325) (Şekil 3) karşımıza çıkmaktadır.

Kazematlı surlar, birbirine paralel uzanan duvar hatları arasına inşa edilen enine duvarlardan meydana gelmektedir. Kazemat, Almanca'da dikdörtgen kutular şeklindeki bölmeleri ifade etmek için kullanılan 'Kastenmauer' 'den türetilmiştir (Mielke, 2018, s. 69). Kazematlı ve sandık duvarlı surlar aynı planın ürünü olup sur içindeki bölmelerin işlevselliği noktasında birbirinden ayrılmaktadır.

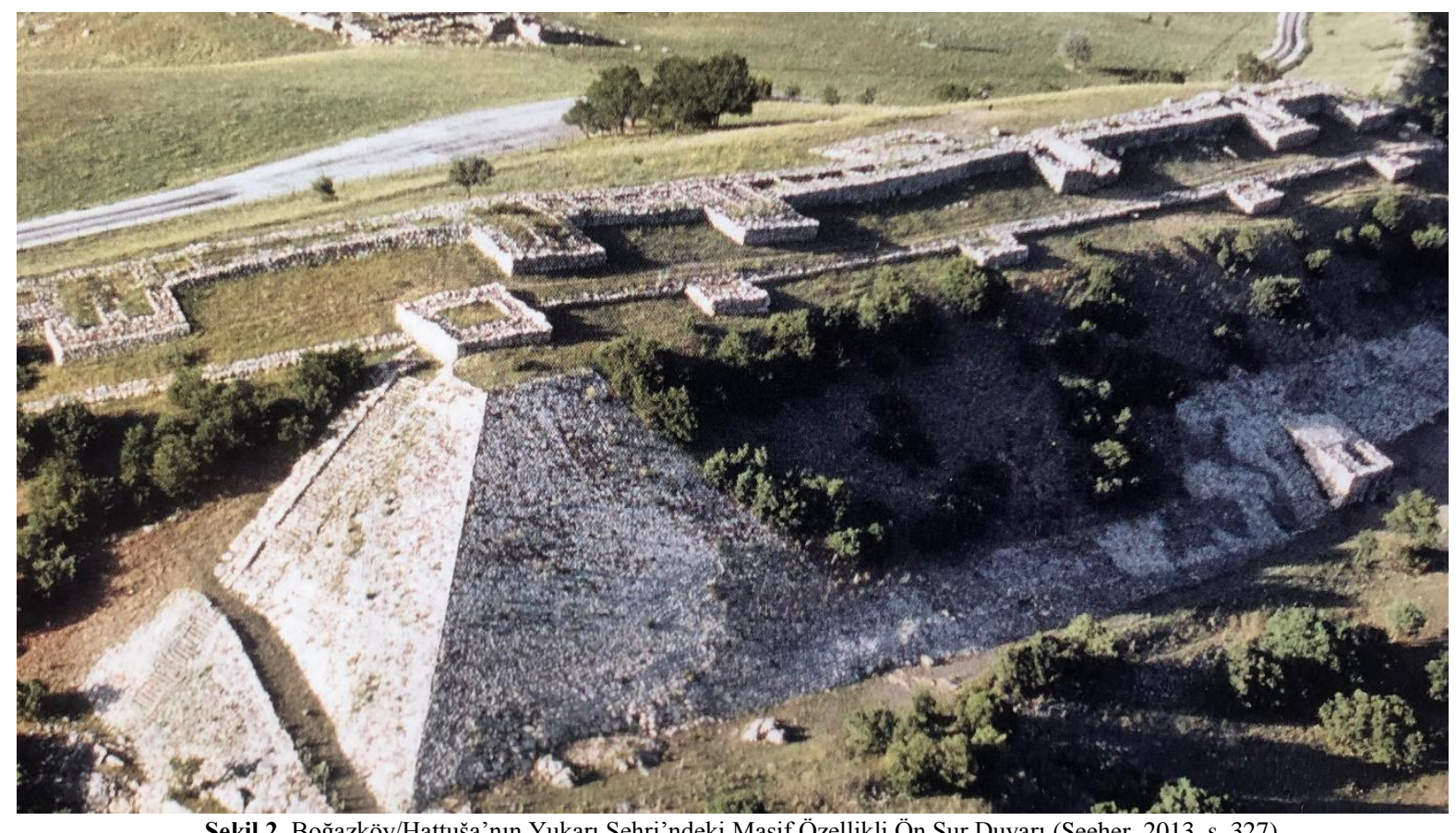

Şekil 2. Boğazköy/Hattuša’nın Yukarı Şehri’ndeki Masif Özellikli Ön Sur Duvarı (Seeher, 2013, s. 327). 
Çukurova Üniversitesi Sosyal Bilimler Enstitüsü Dergisi, Cilt 30, Sayı 2, 2021, Sayfa 28-46

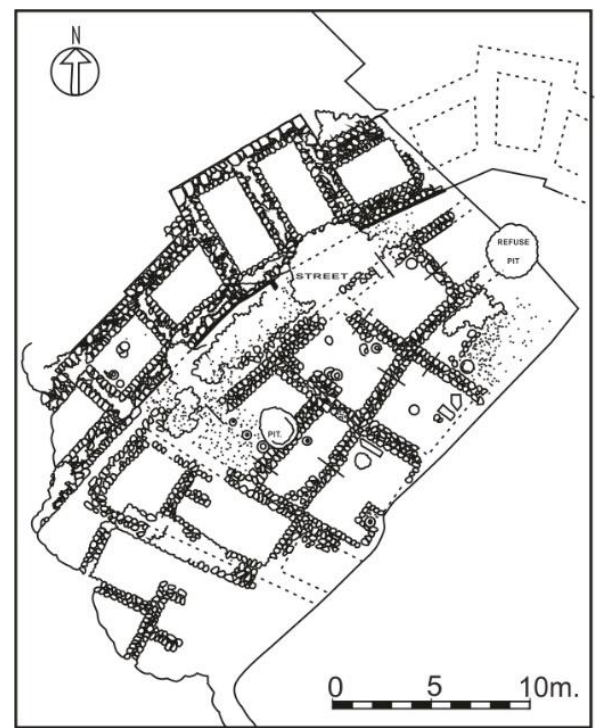

Şekil 3. Mersin-Yumuk Tepe Hitit İmparatorluk Çağı Sur Duvarı (Garstang, 1953, s. 236).

Kazematlı surdaki bölmeler depolama ve yaşam alanı olarak tasarlanırken, sandık duvarlı surdaki bölmeler ise sivil kullanıma imkân tanımayacak şekilde toprak ve moloz dolgusu içermektedir. (Vincenzi \& Rinaldi 2007, s. 417) (Şekil 4). Mielke'ye göre yaşam alanı olarak kullanılan bölmeler sur hattı üzerinde zafiyete yol açmaktadır. (Mielke, 2018, s. 69) Kazematlı sur duvarlarının daha zayıf bir savunma hattına sahip olması sebebiyle Hitit Krallığı'ndaki kullanımının sınırlı kaldığı düşünülmektedir. MÖ 16. yy.'in son çeyreğine tarihlenen Kuşaklı/Šarišša'nın savunma mimarisinde kazematlı sur duvarına dair verilere ulaşılırken sur duvarındaki bazı bölmelerin depolama birimi olarak kullanıldığı tespit edilmiş̧ir (Müller-Karpe, 2004, s. 109110; Müller-Karpe, 2002, s. 471). Orta Hitit Dönemi'nin güçlü bir şekilde temsil edildiği Ortaköy/Šapinuwa'da yürütülen çalışmalarda yerleşmenin sitadel kesimini çevreleyen sur duvarı üzerinde kazemat alanları açığa çıkarılmıștır. Kuleler tarafından sınırlanan ve oldukça uzun dikdörtgen bölmelerden oluşan kazemat alanları depo işlevi görmüştür. (Süel, 2002, s. 165; Süel, 2005, s. 247, res. 2) (Şekil 5). Kazemat ile ilişkili olduğu düşünülen bir diğer veri ise Kilikya'nın doğu ucunda yer alan ve Hitit İmparatorluk Dönemi’ne tarihlenen Tatarlı Höyük savunma sistemi üzerinde açığa çıkarılmıştır (Girginer vd. 2014, s. 185; Cevher, 2020, s. 67). 
Çukurova Üniversitesi Sosyal Bilimler Enstitüsü Dergisi, Cilt 30, Sayı 2, 2021, Sayfa 24-46

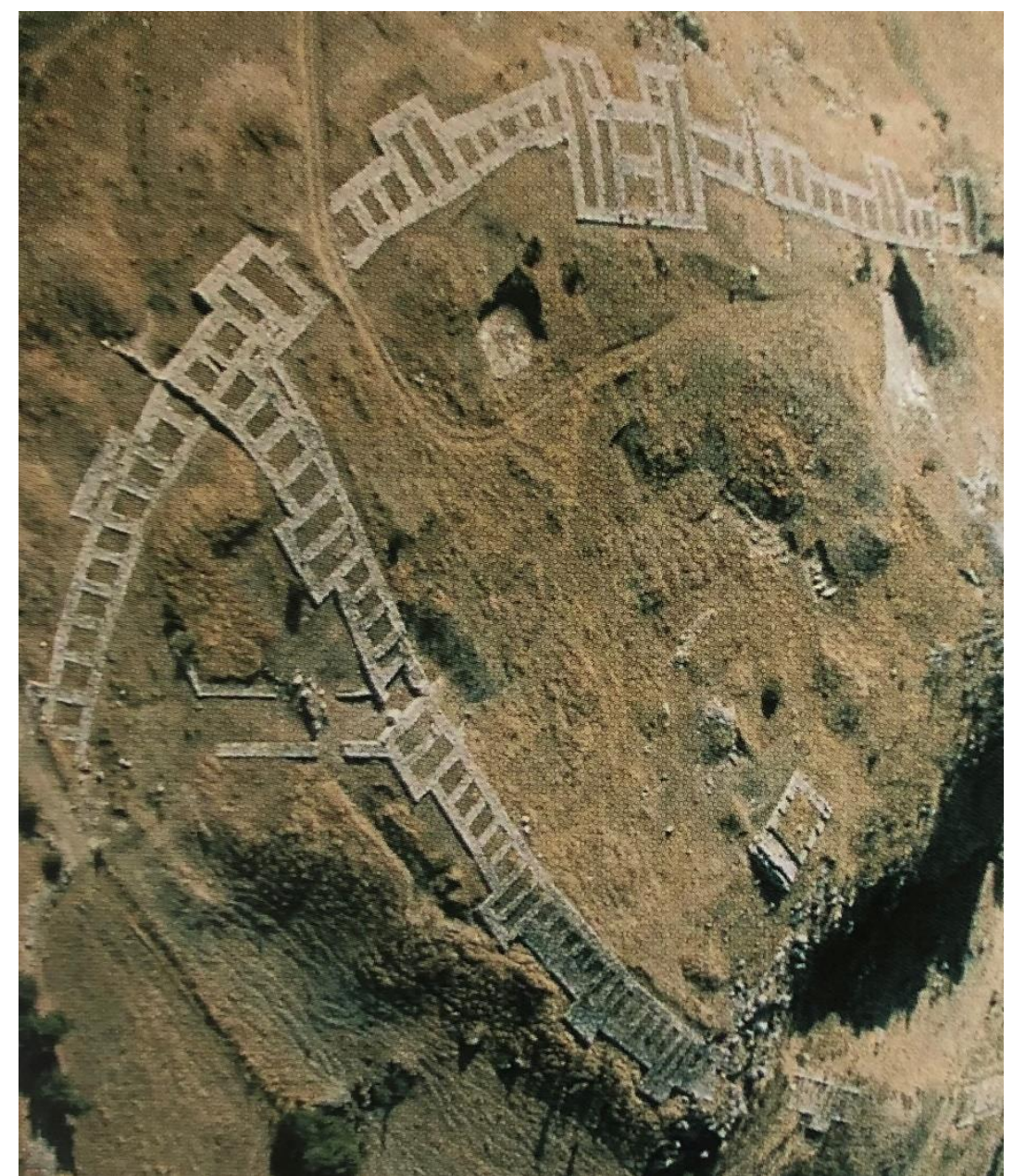

Şekil 4. Boğazköy/Hattuša’daki Büyükkaya'nın Sandık Duvarlı Suru (Seeher, 2013, s. 327).

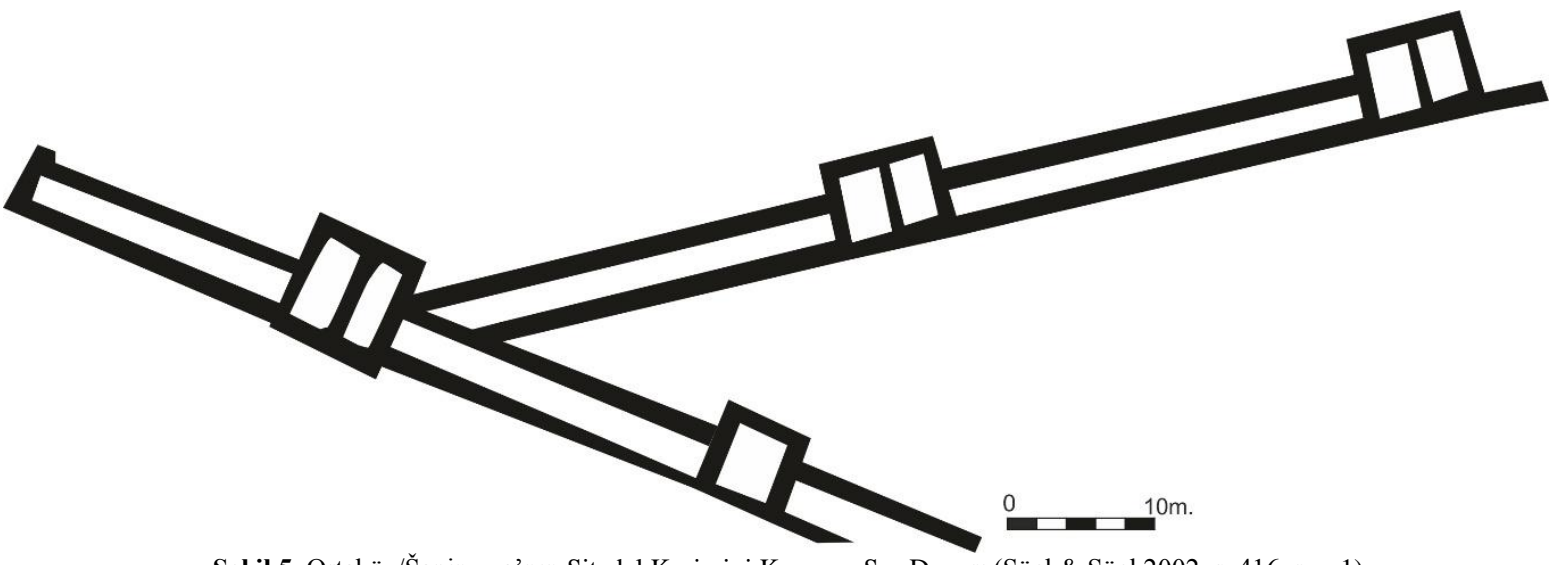

Şekil 5. Ortaköy/Šapinuwa’nın Sitadel Kesimini Koruyan Sur Duvarı (Süel \& Süel 2002, s. 416, res. 1).

Hitit Krallı̆̆ı'nda diğer surlardan farklı olarak standart bir kullanıma ulaşan sandık duvarlı surların Anadolu'daki en erken örneği Assur Ticaret Kolonileri Çağı'na uzanmaktadır. Bu dönemde Alişar'ın (Von der Osten, 1937, s. 4) moloz dolgulu sur duvarındaki bölmelerin benzerlerine daha sonraki süreçte Hitit merkezleri olan Boğazköy/Hattuša (Mielke, 2018, s. 70, fig. 6.4a-d), Kuşakl1/Šarišša (Müller-Karpe \& Müller-Karpe, 2013, s. 221, fig. 1), Alaca Höyük (Koşay \& Akok, 1966, s. 8), Büklükale (Matsumura, 2013, s. 278, fig. 7), 


\section{Çukurova Üniversitesi Sosyal Bilimler Enstitüsü Dergisi, Cilt 30, Sayı 2, 2021, Sayfa 28-46}

Ovaören/Yasshöyük (Şenyurt vd., 2015, s. 108), Kayalıpınar/Šamuha (Müller-Karpe, 2017, s. 65), Yumuktepe (Garstang, 1953, s. 236-237. fig. 151), Tatarlı Höyük (Cevher, 2020, s. 67) ile Gökdin-Kale Höyük'te (Engin, 2017, s. 164) rastlanmaktadır.

Sandık duvarlı surlarda toprak dolgusunun yüksekliği ile ilgili tartışmalar bulunmaktadır. Naumann'a göre sandık içindeki toprak dolgu taş temel seviyesine kadar yükselmektedir. Naumann, kerpiç bedenin başladığı seviyeden itibaren toprak dolgusunun kullanılmadığını bunun sonucunda da sur hattı içinde savunucular için güvenli alanların ortaya çıktığını öne sürmektedir (Naumann, 2007, s. 260). Bir diğer çalışmada da sur duvarının kerpiç üst yapısı içinde, boş alanların olduğu iddia edilerek toprak dolgunun en üst seviyeye çıkması halinde sur duvarının çökme ihtimali ile karşı karşıya kalacağı öne sürülmektedir (Vincenzi \& Rinaldi, 2007, s. 217-222). Her iki görüşte de kerpiç üst yapının toprak dolgusu içermediği değerlendirilirken, bu tarz bir inşa tekniğinde ortaya çıkacak savunma zafiyeti göz ardı edilmiştir. Nitekim bu tekniğe bağlı kalınarak inşa edilen sur duvarları, MÖ II. binyılda kuşatma savaşlarında etkili bir savaş silahı olan koçbaşları ${ }^{3}$ karşısında aşılması kolay bir savunma hattının ortaya çıkmasına neden olacaktır.

Anadolu'da Geç Tunç Çağı'na tarihlenen sur duvarları arasında sandık duvarlı savunma mimarisinin ayrı bir önemi vardır. Bu sur duvarlarına Hitit kentlerinde yaygın olarak rastlanmaktadır. Sandık duvardaki bölmelerin dolgu malzemesi içermesi inşa sürecini kısalttı̆̆ gibi sur inşası sırasında ortaya çıkan mali yükü de aşağı çekmektedir (Mielke, 2018, s. 69-70). Sandık duvarlı sur sistemleri süre ve maliyet konusunda oldukça avantajlı yapılar olmakla beraber, saldırılar karşısında dirençli bir hat oluşturmaları Hitit Krallığı tarafından yaygın bir şekilde kullanılmalarını sağlamıştır (Schachner, 2019, s. 124-125).

\subsection{Kule ve Bastiyonlar}

Hitit kent savunmasında ön plan çıkan mimari unsurlardan bir diğeri de kule ve bastiyon yapılarıdır. Kuleler sur hattından öne taşan ve sur yüksekliğini aşan yapılar olarak tanımlanırken, (Mielke, 2012, s. 75; Keeley vd., 2007, s. 68) bastiyonlar ise kulelerden farklı olarak sur duvarı ile aynı yükseltiyi paylaşan yapıları ifade etmektedir. Arkeolojik çalı̧̧malar sırasında tespit edilen kule veya bastiyon yapılarının sadece taş temelleri korunmuş olarak açığa çıkarılabilmektedir. Üst yapının korunamamış olması sur hattından öne taşan yapıların işlevsel açıdan anlaşılmasını güçleştirmektedir. Sur hattından öne taşan ve daha güçlü temellere sahip yapıların sur yüksekliğini aşabileceği ve dolayısıyla bunların kule olarak tanımlanması gerektiği belirtilmektedir (Keeley vd., 2007, s. 68).

Kule ve bastiyon yapılarının, savunma sistemi içinde oldukça kritik bir rol üstlendiği anlaşılmaktadır. Bu yapılar sur diplerine sı̆̆ınmaya çalışan saldırganların yan taraftan hedef alınmasını kolaylaştırmaktadır. Ayrıca savunma hattı üzerinde geniş görüş mesafesi ve etkili bir ateş gücü sunmanın yanı sıra, sur duvarını destekleyerek savunma hattı üzerinde daha dirençli bir yapının ortaya çıkmasına yardımcı olmaktadır (Keeley vd., 2007, s. 70). Kule kullanımı ile birlikte caydırıcı bir savunma hattı elde edilirken savunma mimarisinde kule yapılarına yer verilmesi inşa maliyetlerinin \%70-80 oranında artmasına neden olmaktadır. Kulelerin inşası ile birlikte ortaya çıkan mali yük, bu yapıların sur duvarından taşması ve sur yüksekliğini aşmasından ileri gelmektedir (Seeher, 2010, s. 35-36).

Hitit merkezlerinde yürütülen kazı çalışmaları sonucunda kule yapılarının varlığını aydınlatan bulgulara ulaşılmıştır. Boğazköy/Hattuša ve Kuşaklı/Šarišša'da ele geçen ve geniş ağızlı kaplarda aplik olarak uygulanan, Kule biçimli kaplar adı ile tanınan eserler birer yapı modeli olup bu kap grubu üzerindeki kulelerin sur yüksekliğini aştı̆̆ görülmektedir. Kule biçimli aplik kapların yanı sıra Boğazköy/Hattuša'da açığa çıkarılan MÖ 14. yy.'a tarihlenen kil kule modeli de Hitit kent savunmasındaki kule yapılarına kanıt oluşturmaktadır (Seeher, 2007, s. 22) (Şekil 6a-b).

Kil kule modelleri dışında, sur duvarından öne taşan yapıların plan özellikleri de kule veya bastiyon kullanımı noktasında fikir sahibi olmamızı sağlamaktadır. Boğazköy/Hattuša'da kule ve bastiyon kullanımı ile ilişkili iki farklı plan ile karşılaşıımaktadır (Seeher, 2010, s. 30-31). Birinci planda sur hattından öne doğru taşan kare planlı iki bölmeli yapılar sur duvarı ile bütünlük oluşturmaktan uzaktır. Birbirleri arasında eşit mesafeler bulunan çıkıntıların, eklenti görünümü sergilemesi sebebiyle bu yapıların sur yüksekliğini aşamayacağı ve dolayısıyla bastiyon olarak değerlendirilmesi gerektiği öne sürülmektedir (Seeher, 2007, s. 20; Seeher, 2010, s.

\footnotetext{
${ }^{3}$ Koçbaşları, kuşatma savaşları sırasında saldırgan grup tarafından sur duvarının kerpiç bedeni üzerinde gedik açma amacına hizmet etmektedir. MÖ III. binyıl sonlarına doğru karşımıza çıkmaya başlayan bu silah Geç Tunç Çağı ile beraber yaygın bir kullanıma sahip olup Yeni Assur Krallığı Dönemi’nde ise kuşatma savaşlarının ayrılmaz bir parçası haline gelmiş̧ir (Eph'al 2009, s. 82-84; Burke, 2008, s. 39-40).
} 
30-33, Abb. 4). Hitit Krallığı'nda bu yapılara Boğazköy/Hattuša'da yer alan Poternli Sur duvarında (Şekil 7a) ve Büyükkaya'da (Şekil 7b) rastlanmaktadır (Seeher, 2010 s. 30, Abb. 4). Hitit merkezlerindeki kullanımından önce bu plan çerçevesinde inşa edilen bastiyon yapılarının en erken örneği Assur Ticaret Kolonileri Çağı'nda KonyaKarahöyük'ün savunma mimarisi üzerinde izlenebilmektedir (Seeher, 2007, s. 20; Naumann, 2007, s. 263).

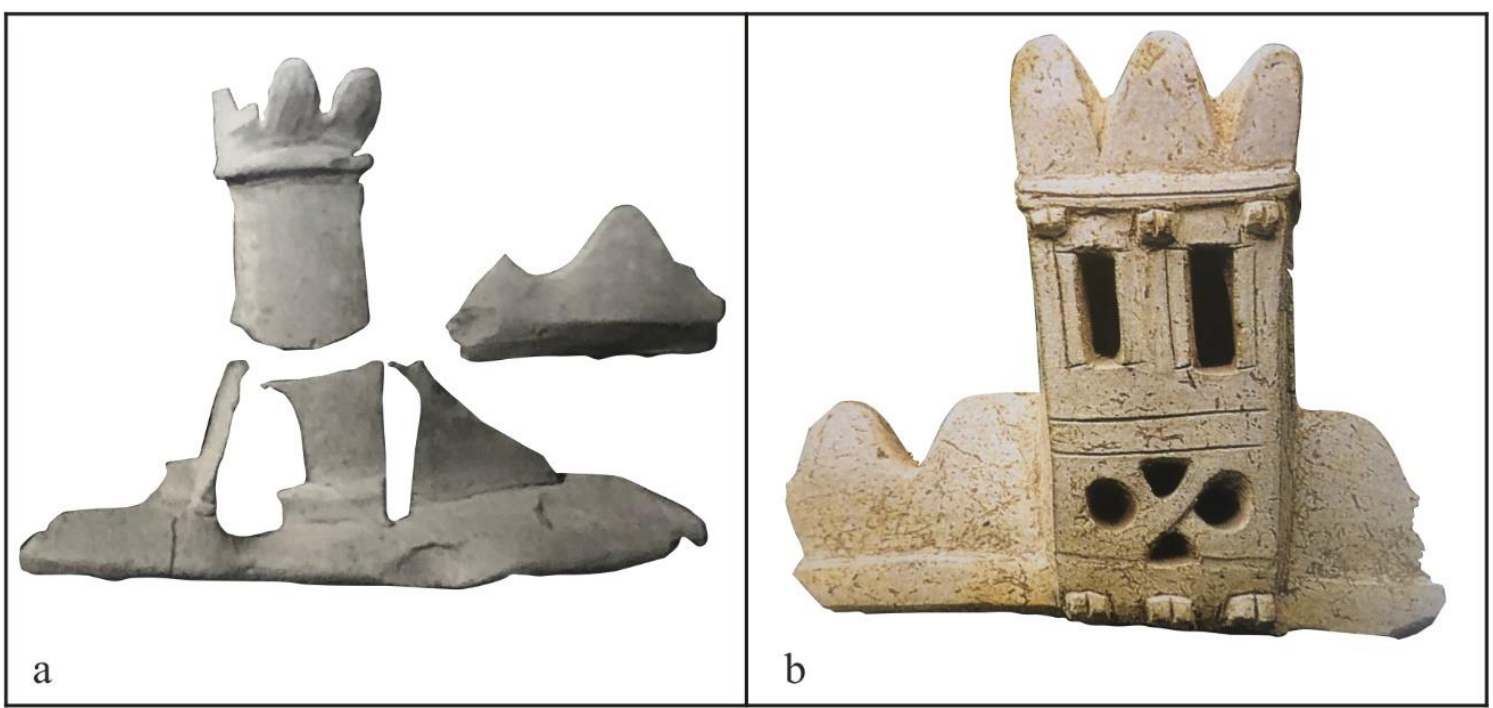

Şekil 6a. Kuşakl1/Šarišša Kil Kule Modeli (Seeher, 2007, s. 22, res. 14c), Şekil 6b. Boğazköy/Hattuša kil kule modeli (Seeher, 2010, s. 34, Abb. 6).

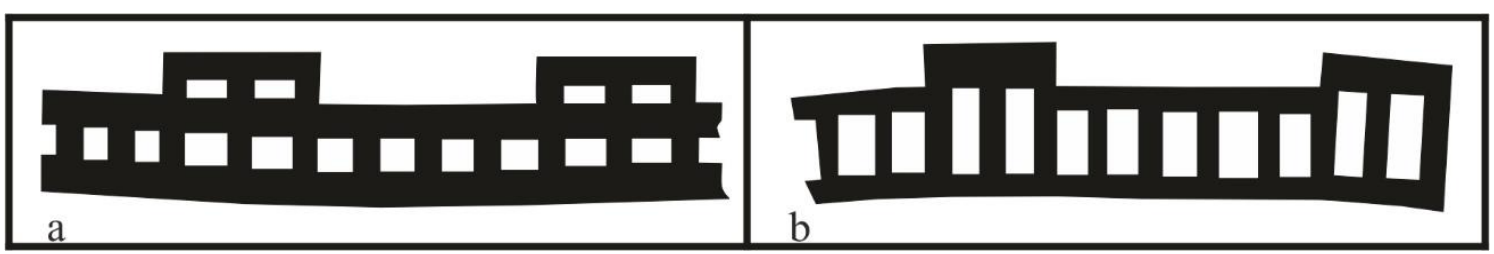

Şekil 7a. Boğazköy/Hattuša'nın Poternli Sur Duvarı ve Bastiyonları (Seeher, 2010, s.31, res. 4b’ten uyarlanmıştır), Şekil 7b. Boğazköy/Hattuša'da yer alan Büyükkaya'nın Kuzey Suru ve Kuleleri (Seeher, 2010, s. 31 res. 4d'den uyarlanmıștır).

Birinci plana bağlı kalınarak inşa edilen yapıların varlığı sınırlı sayıda kalmış olup sonraki süreçte inşa edilen ikinci plan ile birlikte daha gelişmiş bir özellik taşıyan yapılar Hitit merkezlerinde standartlaşarak yaygın bir kullanıma ulaşmıştır. İkinci plan kapsamında inşa edilen kule yapıları kendi içinde bağımsız; ancak sur duvarı ile bütünleşik bir görünüm sergilemektedir. Dikdörtgen planlı iki bölmeden oluşan bu yapılar daha güçlü temellere sahip olmaları sebebiyle kule olarak değerlendirilmektedir (Seeher, 2010, s. 30-33, Abb. 4). Söz konusu ikinci plan çerçevesinde inşa edilen kule yapılarına dair ilk bulgular MÖ 16. yy. sonu 15. yy. başına tarihlendiği düşünülen Boğazköy/Hattuša'nın Yukarı Şehir (Seeher, 2010, s. 30) kesimindeki savuma sistemi üzerinde tespit edilmiştir. Kuşaklı/Šarišša (Seeher, 2010, s. 39), Yumuktepe (Garstang, 1953, s. 236, fig. 152), Ortaköy/Šapinuwa (Süel \& Süel, 2012, s. 414) ve Ovaören (Şenyurt vd., 2015, 117, res. 8) söz konusu kule yapılarının kullanılmış olduğu diğer merkezlerdir. Kuleler yüksek maliyetli yapılar olmalarına rağmen savunma hattı üzerinde sağladığı avantajlardan feragat edilmediği anlaşılmaktadır. Daha sonraki süreç ile beraber gelişmiş bir planlamaya tabi tutulan kule yapıları Hitit savunma mimarisinin vazgeçilmez unsurları haline gelmiştir.

\subsection{Yığma Setler}

Hitit savunma mimarisinde yığma setler de yaygın bir kullanım alanına sahip olmuştur. Yığma setler, sur duvarının inşa edileceği engebeli alanları düzlemek dışında, yükseklik bağlamında elverişli koşullara sahip olmayan topoğrafyanın dış müdahaleler aracılığı ile yükseltmesi amacına hizmet etmektedir (Burke, 2008, s. 48). Topoğrafyadaki dezavantajları gidermekle beraber yığma toprak setler, aynı zamanda saldırı girişimlerini engellemeye yönelik işlevsel özellikler taşımaktadır. Kuşatma savaşları sırasında sur duvarlarına ait temellerin tahrip edilmesi sıklıkla kullanılan bir saldırı taktiğidir (Eph'al, 2009, s. 2009, s. 77). Bu saldırıdan korunmaya yönelik sur diplerine serilen yığma toprak setler, sur temellerinin saldırganlar tarafından aşındırılmasını 
engellemek için kullanılmaktadır (Mielke, 2011b, s. 180). Yı̆̆ma toprak setler aynı zamanda koçbaşı ve kuşatma kulesi gibi mobil kuşatma araçlarının kullanımını sınırlandırıp etkisizleştirme işlevi taşımaktadır (Mielke, 2011b, s. 180). Hitit Krallığı'nda yığma toprak setler Boğazköy/Hattuša (Bittel, 1970, s. 49), Alaca Höyük (Koşay \& Akok, 1966, s. 10) ve Kuşakl1/Šarišša'da (Mielke, 2018, s. 72) tespit edilmiştir. Boğazköy/Hattuša'nın Yukarı Şehir kesiminde yer alan ve yığma toprak dolgudan oluşan Yerkapı rampası, sahip olduğu ölçüler bakımından anıtsal karakter sergilemektedir. Yerkapı rampasının bulunduğu alandaki topoğrafyanın savunma açısından uygun özellikler taşıması sebebiyle bu yapının askerî amaçlı kullanımdan ziyade krallı̆̆ın ihtişamını yansıtan ideolojik işleve sahip olduğu öne sürülmektedir (Seeher, 2013, s. 326).

\subsection{Kent Kapıları}

Kent kapıları, sur hattı içindeki delikler olarak kabul edilirken bu yapılar savunma mimarisinin en zayıf halkasını oluşturmaktadır (Burke, 2008, s. 67). Kapılar genellikle sivil ulaşıma uygun alanlar üzerinde yer almaktadır. Bu durum kent kapılarını potansiyel saldırı noktası haline getirmektedir. Kapılar ilk saldırı noktaları olmaları sebebi ile korunaklı bir plan etrafinda inşa edilmektedir. Kent girişinin bulunduğu alanlardaki anıtsal karakterli kule yapıları, kent kapılarının neden olduğu güvenlik kaygılarının bir yansımasıdır (Mielke, 2011c, s. 94-95).

Hitit kentlerinde açığa çıkarılan anıtsal giriş kapılarındaki kuleler, genellikle standart bir planlamaya tabi tutulmuştur. Hitit kapılarında giriş koridorundan önce ön avlu bulunmaktadır. Ön avludan sonra iki geçişli ve tek odalı bir düzenleme ile karşılaşılmaktadır (Şekil 8). Parabol şeklinde inşa edilen giriş kapısının sağ ve sol tarafında yer alan dört-altı bölmeli kuleler anıtsal boyutlarda inşa edilmektedir. Hitit merkezlerindeki kullanımından önce bu plan özelliklerini taşıyan kent kapılarına MÖ II. binyıl başlarında Konya-Karahöyük (Alp, 1959, s. 691) ve Kültepe-Kaniş/Neša'da (Özgüç, 1999, s. 11, Plan 1-2) rastlanmaktadır. Hitit Krallığı ile birlikte söz konusu kent kapıları Boğazköy/Hattuša (Puchstein, 1984, s. 179), Alişar (Von der Osten, 1937, s. 8, fig. 53), Alaca Höyük (Koşay \& Akok 1966, s. 10-11) ve Oymaağaç/Nerik’te? (Czichon, 2013, s. 306, fig. 8) açığa çıkarılmıştır.

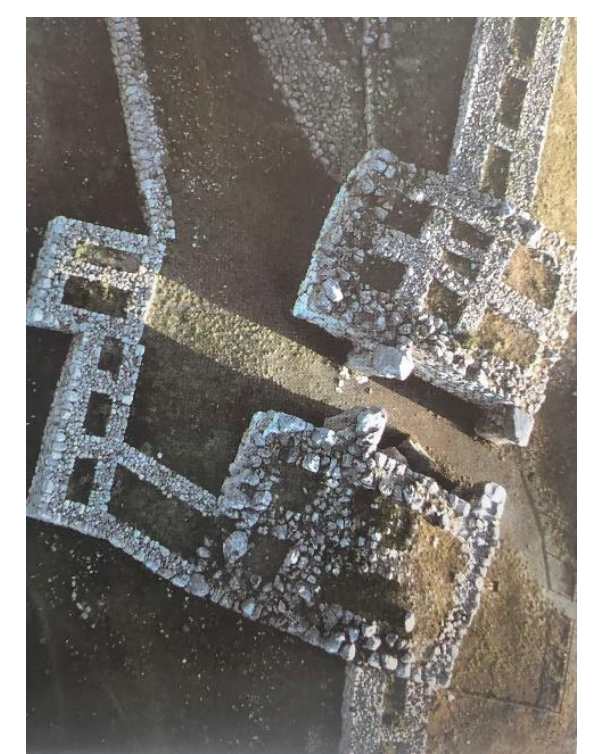

Şekil 8. Boğazköy/Hattuša’nın Yukarı Şehir Kral Kapısı (Seeher, 2006a, 94).

Hitit savunma mimarisinde sur duvarlarında olduğu gibi giriş kapılarında da standartlaşma eğilimi göze çarparken Hitit merkezlerinde yapılan çalışmalar sırasında Boğazköy/Hattuša Aşağı Kent Güney Kapısı (Bittel, 1957, s. 18-20. Abb. 14-15), Büyükkaya Kapısı (Schachner, 2019, s. 124, res. 66), Kuşakl1/Šarišša Kuzeybatı Kapısı (Mielke, 2004, s. 147-148) (Şekil 9) ve Güneydoğu Kapısı'nın (Müller-Karpe, 2000, s. 311, 316) standart plandan farklı özellikler taşıdığı tespit edilmiştir. Bu merkezlerde tespit edilen giriş kapıların benzerlerine Orta 
Tunç Çağı'nda Suriye-Filistin merkezlerinde sıklıkla rastlanmaktadır ${ }^{4}$ (Burke, 2008, s. 68-70). Suriye Tipi Kent Kapıları (Kempinski, 1992, s. 197) olarak tanımlanan bu yapılar üç geçişli ve iki odalı olup, standartlaşmış Hitit kent kapılarına oranla daha dar bir ön avluya ve oldukça uzun bir giriş odasına sahiptir (Gregori, 1986, s. 83102). Hitit merkezlerinde tespit edilen üç geçişli kapı yapılarının Suriye-Filistin etkisinden ziyade teknik ihtiyaçlar sonucu ortaya çıktığı düşünülmektedir. Giriş koridorunun ortasında yer alan duvar hattının çatıyı desteklemek için kullanılmış olduğu, dolayısıyla Hitit Krallığı'nda üç geçişli kapı tipinin görülmesinde teknik gereksinimlerin belirleyici olduğu iddia edilmektedir (Mielke, 2018, s. 73).

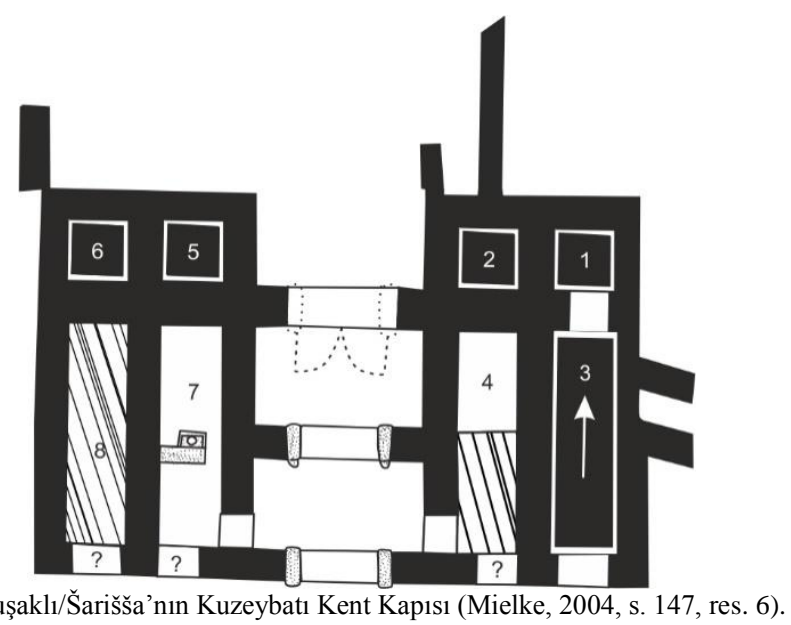

\subsection{Poternler}

Anıtsal kent kapıları dışında kente giriş sağlayan yapılardan bir diğeri de arka kapı, yan kapı anlamına gelen potern (Latince: posterula) yapılarıdır (Seeher, 2006b, s. 38). Sur duvarının içine veya altında inşa edilen yapılardan oluşan poternlerin, yaya trafiğini hızlandırmak dışında aynı zamanda askerî kullanıma hizmet ettiği öne sürülmektedir (Miglus, 2005, s. 605).

Bugüne kadar açığa çıkarılmış olan poternler plan özellikleri bakımından iki grup altında incelenmektedir. Birinci gruptaki poternler sur duvarlarına açılan dar kapı aralıklarından oluşmakta olup MÖ 15-14. yy. tarihlenen ve Hitit etkileri taşıyan Ugarit poterni bu gruba girmektedir (Helms, 1975, s. 134; Yon, 2006, s. 33, fig. 18a). İkinci gruptaki poternler ise Anadolu'ya özgü olup bu yapılar bindirmeli sahte kemer tekniğine göre inşa edilerek sur duvarının altından geçirilmektedir (Naumann, 2007, s. 313).

İkinci gruptaki potern yapılarının en erken örneği MÖ II. binyıl başlarında Alişar'da (Von der Osten \& Schmidt, 1930, s. 187, fig. 166) açığa çıkarılmıştır. Hitit Krallı̆̆ı ile birlikte söz konusu potern yapıları Boğazköy/Hattuša (Puchstein, 1984, s. 38, Abb. 26-27), (Şekil 10a), Alaca Höyük (Arık, 1937, s. 9) (Şekil 10b) ve Külhöyük’te (Mermerci, 1994, s. 19) karşımıza çıkmaktadır.

\footnotetext{
${ }^{4}$ Suriye Tipi Kent Kapıları, Alalah (Wooley 1955, s. 146, fig. 55), Kargamış, (Wooley, 1921, s. 71-73, Plate 16), Tell Tuqan (Baffi, 2014, s. 166, fig. 4) ve Shechem (Herzog, 1997, s. 142, fig. 4.14) de izlenebilmektedir.
} 


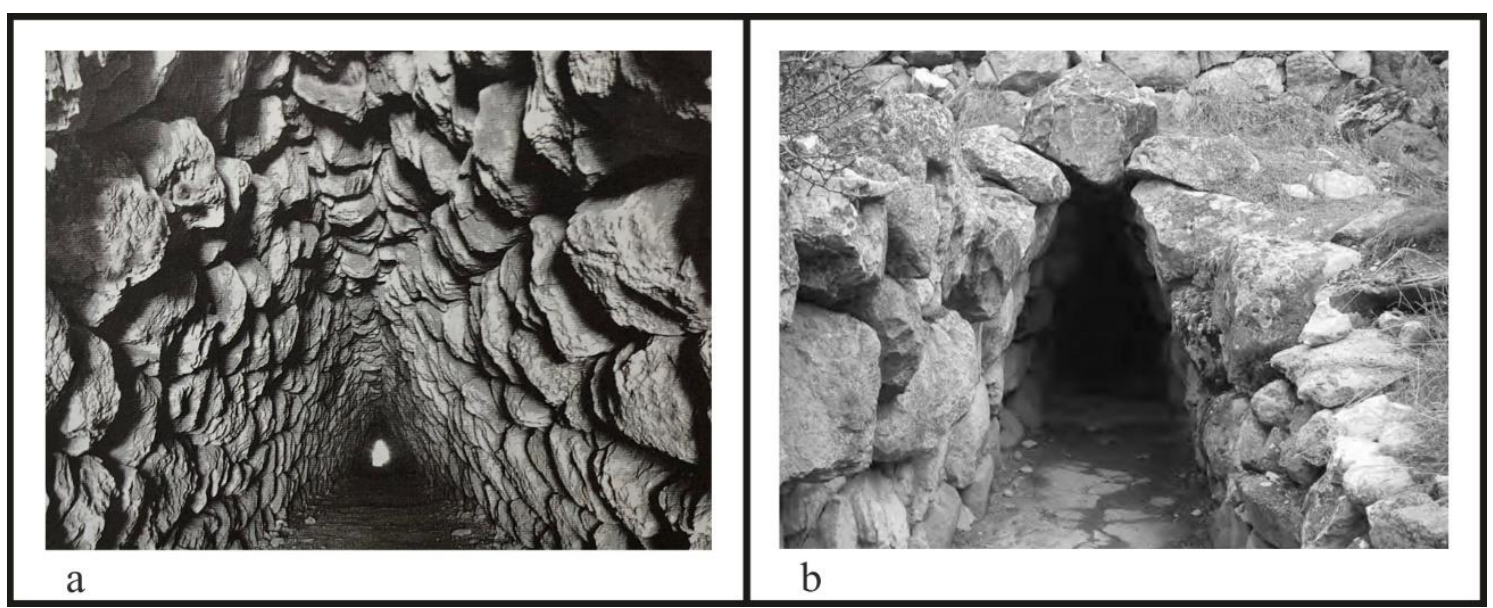

Şekil 10a. Boğazköy/Hattuša, Yukarı Şehir, Yerkapı Poterni (Seeher, 2006a, 63), Şekil 10b. Alaca Höyük Poterni (Maner, 2013, 425).

Hitit kentlerinde açığa çıkarılan potern yapılarının askerî işlevi ile ilgili tartışmalar bulunmaktadır. Naumann, poternlerin askerî amaçlı kullanımını öne çıkarırken bu yapıların kuşatma dönemlerinde düşman birliklere ani saldırılar gerçekleştirmek için kullanılmış olduğunu ifade etmektedir (Naumann, 2017, s. 312). Seeher, poternlerin askerî işlevine dair ileri sürülen görüşleri ikna edici bulmamaktadır. Seeher'e göre poternler askerî amaçlı kullanıma sahip olmaları durumunda çıkış noktalarının gizli tutulması gerekmektedir (Seeher, 2013, s. 328); ancak Hitit merkezlerindeki potern yapılarının hiçbirinde gizlemeye yönelik herhangi bir mimari düzenleme tespit edilememiştir. Diğer bir çalışmada ise Schachner de poternler ile ilgili benzer düşünceyi savunmaktadır. Schachner'e göre oldukça uzaktan fark edilebilen Yerkapı poterninin gizlenmesine yardımcı olacak mimari unsurlara rastlanmaması söz konusu yapıların askerî işlevini tartışmalı hâle getirmektedir (Schachner, 2019, s. 132). Ayrıca Boğazköy/Hattuša'daki Yerkapı poterni dışında Hitit merkezlerinde açığa çıkarılan diğer poternlerde kapı kullanımına dair bulgulara ulaşılmaması, (Naumann, 2007, s. 313) potern yapılarının askerî işlevinin sorgulanmasına neden olmuştur.

\section{SONUÇ}

Hitit Krallığı'nın ülke savunması politikaları çerçevesinde gerçekleştirdiği tampon bölgeler oluşturma, güvenlikli sınır karakolları inşa etme ve demografik yapıyı değiştirme faaliyetleri günümüz sınır savunma politikalarında da geçerliliğini korumaya devam etmiştir. Sınır hatlarında mutlak egemenliği amaçlayan bu politikalar merkezî otoritenin güçlü olduğu dönemlerde etkin bir şekilde uygulanabilirken yönetme kabiliyetin zayıf düştüğü dönemlerde ise sınır hatları üzerindeki güvenliğin tesis edilemediği anlaşılmaktadır. Hitit Krallığı tarafından uygulanan ve yıkılışa kadar geçerliliğini koruyan ülke savunması politikaları kısa vadeli çözümler üretirken uzun vadede bu politikalar başarısızlığa uğramıştır. Hitit merkezî otoritesinde yaşanan zafiyet sınırlarda geçişken bir yapının ortaya çıkmasına neden olurken bu durumdan faydalanan düşman krallıklar Hitit Ülkesi üzerine düzenledikleri baskınlar sonucunda krallığın sınır hatları üzerindeki egemenliğini sarsmayı başarmışlardır. Yıkılışa kadar devam eden Kaška saldırıları ile beraber Batı Anadolu'da sonu gelmeyen isyancı eylemler ülke savunması bağlamında yaşanan başarısızlığa kanıt oluştururken Hitit ülkesinin sınır hatlarında ortaya çıkan güvenlik açığı korunaklı yapısı ile ön plana çıkan tahkimli kentlerin varlığını elzem kılmıştır. Hitit Krallığı'nda standart hâle gelen kulelerce desteklenen sandık duvarlı surlar ile kent kapıları ülke savunması kapsamında yaşanan aksaklıkların bir sonucudur. Anadolu'daki siyasi yapının kaygan zemini karşısında, Hitit Krallığı inşa ettiği korunaklı ve görkemli kent savunması ile bölge üzerindeki hâkimiyetini uzun süre konsolide etmeyi başarmıştır. Hititler'de anıtsal özellikler sergileyen savunma mimarisinin katı bir savunma hattı oluşturmanın dışında aynı zamanda ideolojik açıdan Hitit Krallığı'nın sahip olduğu gücü ve ihtişamı yansıtma aracı olarak kullanılmış olduğu anlaşılmaktadır.

Hitit kültürü üzerinde belirgin bir etkiye sahip olan Assur Ticaret Kolonileri Çağı'nın Hitit merkezlerinde açığa çıkarılan kent savunmasının oluşumunda da pay sahibi olduğu anlaşılmaktadır. Hitit Krallığı tarafından standart bir uygulamaya tabi tutulan sur duvarları, kent kapıları ve potern yapılarının en erken örnekleri Konya/Karahöyük, Alişar ve Kültepe-Kaniş/Neša'nın MÖ II. binyıl başına tarihlenen kent savunması üzerinde izlenebilmektedir. Kökleri Assur Ticaret Kolonileri Çağı'na uzanan kent savunmasının homojen bir görünüm 
sergilemesinde Hitit krallarının belirleyici bir misyon üstlendiği anlaşılmaktadır. Savunma mimarisinin inşa sürecinde kullanılacak malzemenin temini, işlenmesi ve gerekli iş gücünün toplanması organize ve etkili bir planlama gerektirmektedir. Kent savunmasının ayağa kaldırılması sırasında ihtiyaç duyulan iş gücünün üretim ve tedarik zincirinden kopartılarak inşa faaliyetlerine kaydırılması merkezî otoritenin bilgisi ve onayı dâhilinde mümkün olabilmektedir. Hitit krallarının bu sürece doğrudan müdahil olduğu ve tahkimli kentler inşa etmeye özen gösterdikleri anlaşılmaktadır. Hitit krallarının tahkimli kentlerin inşa sürecinde aktif bir rol üstlenmeleri Anadolu'daki kent savunmasının daha önceki dönemlerden farklılaşarak standart bir görünüm kazanmasını sağlamıştır.

\section{KAYNAKLAR}

Alp, S. (1949). Hititler'de sosyal sınıf NAM.RA'lar ve ideogramının Hititçe karşılığı. Belleten, 13 (50), $245-270$.

Alp, S. (1957). Karahöyük kazısı. Belleten, 21 (84), 660-662.

Alp, S. (1959). Karahöyük kazısı. Belleten, 23 (92), 691-692.

Alparslan, M. (2017). The Upper Land: Borders of a political and geographical landscape. M. Alparslan (Ed.), Places and spaces in Hittite Anatolia I: Hatti and the east (s. 177-183). Türk Eskiçağ Bilimleri Enstitüsü.

Arık, RO (1937). Türk Tarih Kurumu tarafindan yapılan Alaca Höyük hafriyatı, 1935 'teki çalışmalara ve keşiflere ait ilk rapor. Türk Tarih Kurumu Yayınları.

Baffi, F. (2014). The defences at Tell Tuqan in the 2nd Millennium BC. F. Baffi, R. Fiorentino ve L. Peyronel (Eds.), Tell Tuqan excavations and regional perspectives: Cultural developments in inner Syria from the Early Bronze Age to the Persian/Hellenistic Period (s. 163-188). Congedo.

Beal, RH (1992). The organisation of the Hittite military. Carl Winter.

Beckman, GM, Bryce, T. \& Cline, E. (2011). The Ahhiyawa texts, JL. Theodore (Ed.). Society of Biblical literature.

Beyer, D. (2006). Zeyve Höyük (Porsuk) the excavations 2004. Kazı Sonuçları Toplantısı, 27 (2), 65-72.

Bittel, K. (1957). Untersuchungen in der Altstadt, Mitteilungen der Deutschen Orient Gesellschaft, 89, 6-25.

Bittel, K. (1970). Hattusha, the capital of the Hittites. Oxford University Press.

Bryce, T. (1986). The boundaries of Hatti and Hittite border policy. Tel-Aviv, 13-14, 85-102. https://doi.org/10.1179/tav.1986.1986.1.85

Bryce, T. (2003). Hitit dünyasında yaşam ve toplum. Dost Yayınevi.

Bryce, T. (2005). The Kingdom of Hittites. Oxford University Press. https://doi.org/10.1093/acprof:oso/9780199281329.001.0001

Burke, AA (2008). Walled up to Heaven: The evolution of Middle Bronze Age fortification strategies in the Levant. President and Fellows of Harvard College. https://doi.org/10.1163/9789004376687

Cevher, M. (2020). Tatarlı Höyük Geç Tunç Çağı savunma sistemi ile ilgili bir değerlendirme. KS Girginer, G. Dardeniz, A. Gerçek, F. Erhan, E. Genç, İ. Tuğcu, Ö. Oyman-Girginer, MC. Fırat, H. Gerçek ve MF Tufan. (Eds.), MORS IMMATURA, Amanoslar'ın gölgesinde Hayriye Akıl anı kitabı (s. 63-74). Ege Yayınları. 
Czichon, RM (2013). Oymaağaç Höyük/Nerik(?). M. Doğan-Alparslan ve M. Alparslan (Ed.), Hititler bir Anadolu imparatorluğu (s. 298-313). Yapı Kredi Yayınları.

de Martino, S. (2003). Annali e res gestae Antico Ittiti. Italian University Press.

Dönmez, Ş. (2017). The contribution of new research to Hittite historical geography of Amasya Pprovince. M. Alparslan (Ed.), Places and spaces in Hittite Anatolia I: Hatti and the East (s. 75-99). Türk Eskiçă Bilimleri Enstitüsü.

Engin, A. (2017). Second Millenium BC settlement patterns in the east of the Upper Kizilırmak Basin. M. Alparslan (Ed.), Places and spaces in Hittite Anatolia I: Hatti and the East (s. 159-176). Türk Eskiçă Bilimleri Enstitüsü.

Erkanal, H. \& Şahoğlu, V. (2016). Limantepe an Early Bronze Age trade center in Western Anatolia: Recent investigation. E. Pernicka, S. Ünlüsoy ve W. Blum (Ed.), Early Bronze Age Troy: Chronology, cultural development and interregional contacts, proceddings of an international conference held at the University of Tübingen May 8-10, 2009 (s. 157-166). Rudolf Habelt GmbH.

Eph'al, I. (2009). The city besieged, siege and its manifestations in the Ancient Near East. Brill. https://doi.org/10.1163/ej.9789004174108.i-214

Ertem, H. (1980). Hitit Devleti'nin iki eyaleti Pala-Tum(m)ana ile yakın çevresindeki yerlerin lokalizasyonu üzerine yeni bir değerlendirme. Ankara Üniversitesi Dil ve Tarih-Coğrafya Fakültesi Yayınları.

Frangipane, M. (2011). Arslantepe-Malatya: A prehistoric and early historic center in Eastern Anatolia, SR Steadman ve G. McMahon (Eds.), The Oxford handbook of Ancient Anatolia 10.000-323 BCE (s. 968992). Oxford University Press. https://doi.org/10.1093/oxfordhb/9780195376142.013.0045

Garstang, J. (1953). Prehistoric Mersin, Yümük Tepe in southern Turkey. Clarendo Press.

Garstang, J. \& Gurney OR (1959). The geography of the Hittite Empire. British Institute of Archaeology at Ankara.

Gates, MH (2009). 2007 season at Kinet Höyük (Yeşil-Dörtyol, Hatay). Kazı Sonuçları Toplantısı, 30 (2), 351 368.

Gates, MH (2011). Southeren and southeastern Anatolia in the Late Bronze Age. SR Steadman ve G. McMahon (Eds.), The Oxford Handbook of Ancient Anatolia (s. 393-414). Oxford University Press. https://doi.org/10.1093/oxfordhb/9780195376142.013.0017

Girginer, KS, Oyman-Girginer, Ö., Akıl, H., Cevher, M \& Aklan, İ. (2014). 2012 Tatarlı Höyük kazıları. Kazı Sonuçları Toplantısı, 35 (2), 182-196.

Gregori, B. (1986). Three-Entrence City Gates of the Middle Bronze Age in Syria and Palestine. Levant, 18, 83102. https://doi.org/10.1179/lev.1986.18.1.83

Gurney, OR (2003). The Upper Land, matum elitum, G. Beckman, R. Beal ve G. McMahon (Eds.), Hittite studies in honor of Harry A. Hoffner Jr. On the occasion of his 65th birthday (s. 119-126). Eisenbrauns.

Gülçur, S. (2012). The Chalcolithic Period in Central Anatolia Aksaray-Niğgde region. Origini, XXIV, 213-227. 
Çukurova Üniversitesi Sosyal Bilimler Enstitüsü Dergisi, Cilt 30, Sayı 2, 2021, Sayfa 24-46

Hawkins, JD (1995). The hieroglyphic inscription of the Sacred Pool at Hattusa (SUDBURG), with an archaeological introduction by Peter Neve. Harrassowitz Verlag.

Helms, SW (1975). Posterns in Early Bronze Age fortifications of Palestine. Palestine Exploration Quarterly, 107, 133-150. https://doi.org/10.1179/peq.1975.107.2.133

Herzog, Z. (1997). Archaeology of the city, urban planing in Ancient Israel and its social implications. Emery and Claire Yass Archaeology Press.

Hoffner, HA (2002). The treatment and long-term use of persons captured in battle according to the Maşat texts, KA Yener ve HA Hoffner Jr. (Eds.), Recent developments in Hittite Archaeology and history (s. 61-72). Eisenbrauns.

Hoffner, HA (2009). Letters from the Hittite Kingdom. Writings from the ancient world, 15. Society of Biblical literature.

Houwink ten Cate, PHJ (1984). The history of warfare according to Hittite sources: The Annals of Hattusilis I (part II). Anatolica, 11, 47-82.

Jean, E. (2006). The Hittites at Mersin-Yumuktepe: Old problems and new directions. Byzas, 4, 311-332.

Keeley, LH, Fontana, M. \& Quick, R. (2007, 5 Mart). Baffles and bastions: The universal features of fortifications. Journal of Archaeological Resource, 15, 55-95. https://doi.org/10.1007/s10814-006-9009-0

Kempinski, A. (1992). The Middle Bronze Age. A. Ben-Tor (Ed.), The Archaeology of Ancient Israel (s. 59210). Yale University Press.

Kern, PB (1999). Ancient siege warfare. Souvenir Press.

Konyar, E. (2006). Old Hittite presence in the east of the Euphrates in the light of the stratigraphical data from İmikuşağı (Elazığ). Byzas, 4, 333-348.

Koşay, HZ \& Akok, M. (1966). Türk Tarih Kurumu tarafından yapılan Alaca Höyük kazısı 1940-1948'deki çalışmalara ve keşiflere ait ilk rapor. Türk Tarih Kurumu Basımevi.

Kryszeǹ, A. (2012). Towards a reconstruction of Hittite geography the case of Šllapa. Palamedes, a Journal of Ancient History, 7, 5-24.

Macqueen, JG (2009). Hititler ve Hitit çă̆ında Anadolu. Arkadaş Yayınevi.

Maner, Ç. (2013). Corbelled vaults in Hittite an Mycenaean fortificaion architecture, A. D'agostino, G. Guarducci, V. Orsi ve S. Valentini (Eds.), Identiy and connectivity proceedingsof the 16th symposium on Mediterreanean archaeology (s. 419-426). Archaeopress.

Manuelli, F. (2013). Arslanepe, Late Bronze Age Hittite influence and local traditions in an Eastern Anatolian community. Spienza Universita di Roma.

Manuelli, F. (2017). Hatti and the East. A reassessment of the archaeological evidence from the Upper Euphrates Region: Places, spaces and artifacts. M. Alparslan. (Ed.), Places and spaces in Hittite Anatolia I: Hatti and the East (s. 137-158). Türk Eskiçağ Bilimleri Enstitüsü.

Matessi, A \& Tomassini Pieri, BM (2017). South-central: Archaeology. M. Weeden ve LZ Ullmann (Eds.), Hittite landsape and geography (s. 89-105). Brill. 
Çukurova Üniversitesi Sosyal Bilimler Enstitüsü Dergisi, Cilt 30, Sayı 2, 2021, Sayfa 28-46

Matsumura, K. (2013). Büklükale. M. Doğan-Alparslan ve M. Alparslan (Eds.), Hititler bir Anadolu imparatorluğu (s. 274-281). Yapı Kredi Yayınları.

Mellaart, J. (1984). Some reflections on the history and geography of Western Anatolia in the late fourteenth and thirteenth centuries BC. Anadolu Araştırmaları, 10, 215-231.

Mermerci, D. (1994). Oyaca Kasabası Külhöyük 1992 kurtarma kazısı. Müze Kurtarma Kazıları Semineri, 4, 17 38.

Mielke, DP (2004). Untersuchungen in Kuşaklı 2003, Die Ausgrabung des Nordwest-Tores. Mitteilungen der Deutschen Orient-Gesellschaft, 136, 145-171.

Mielke, DP (2011a). Key sites of the Hittite Empire. G. Mcmahon ve S. Stedman (Eds.), The Oxford handbook of Ancient Anatolia 10.000-323 BCE (s. 1031-1054). Oxford University Press. https://doi.org/10.1093/oxfordhb/9780195376142.013.0048

Mielke, DP (2011b). Hittite cities: Looking for a concept. H. Genz ve DP Mielke. (Eds.), Insight into Hittite history and archaeology (s. 153-194). Peeters Publishers.

Mielke, DP (2011c). Stadttor. Reallexikon der Assyriologie und Vorderasiatischen Archäologie, 13 (1/2), 91-97.

Mielke, DP (2012). Fortification and fortification strategies of mega-cities in the Ancient Near East, R. Matthews, J. Curtin, M. Seymour, A. Fletcher, A. Gasco ve R. Chapman (Eds.), Proceedings of the 7th. international congress on the archaeology of the Ancient Near East, mega-Cities \& mega-Sites: The archaeology of consumption \& disposal; landscape, transport \& communication 1 (s. 74-91). Harrass Owitz Verlag.

Mielke, DP (2018). Hittite fortifications between function and symbolism. A. Ballmer, M. Fernandez-Götz ve DP Mielke (Eds.), Understanding ancient fortifications between regionality and connectivity (s. 63-81). Oxbow Books.

Miglus, PA (2005). Poterne. Reallexikon der Assyriologie und Vorderasiatischen Archäologie, 10, 605-608.

Miller, JL (2013). Royal Hittite instructions and related administrative texts. writings from the ancient world book. Society of Biblical Literature.

Murat, L. (2008, 1 Ekim). Hitit tarihi coğrafyasında Hakmiš ve Ištahara Ülkeleri’nin konumu. Tarih Araştırmaları Dergisi, 44, 181-204. https://doi.org/10.1501/Tarar_0000000414

Murat, L. (2016). Anadolu'da Kaškalar. Hel Yayınları.

Müller-Karpe, A. (2000). Kuşaklı 1998 yılı 6. kazı çalışmaları hakkında ön rapor. Kazı Sonuçları Toplantısı 21 (1), 309-320.

Müller-Karpe, A. (2002). Kuşakl1-Sarissa Yukarı Ülke'de bir kült merkezi, J. Wenzel. (Ed.), Hititler ve Hitit İmparatorluğu, 1000 tanrılı halk (s. 470-474). Kunst - und Ausstellungshalle.

Müller-Karpe, A. (2004). Untersuchungen in Kuşaklı 2002. Mitteilungen der Deutschen Orient Gesellschaft, $136,103-135$.

Müller-Karpe, A. (2017). The east: Archaeology, the Upper Land, Azzi Hayaša, Išuwa. M. Weeden ve LZ Ullmann (Eds.), Hittite landscape and geography (s. 58-74). Brill. 
Çukurova Üniversitesi Sosyal Bilimler Enstitüsü Dergisi, Cilt 30, Sayı 2, 2021, Sayfa 24-46

Müller-Karpe, A. \& Müller-Karpe, V. (2013). Kuşaklı-Sarissa. M. Doğan-Alparslan ve M. Alparslan. (Eds.), Hititler bir Anadolu imparatorluğu (220-227). Yapı Kredi Yayınları.

Müller-Karpe, V. \& Müller-Karpe, A. (2016). Kayalıpınar/Samuha'da yapılan kazı çalışmaları. Kazı Sonuçları Toplantısı, 38 (3), 297-316.

Naumann, R. (2007). Eski Anadolu mimarlığı. Türk Tarih Kurumu Yayınları.

Nossov, K. (2008, 6 Şubat). Hittite fortifications c. 1650-700 BC. Osprey Publishing.

Oded, B. (1979). Mass deportation and deportees in the Neo-Assyrian Empire. Reichert.

Ökse, T. (2008). Sivas Bölgesi’nin Hitit yerleşim tarihi ve kökenleri. T. Tarhan, A. Tibet ve E. Konyar (Eds.), Muhibe Darga armağanı (s. 365-374). Sadberk Hanım Müzesi Yayını.

Özgüç, T. (1999). Kültepe-Kaniş/Neşa sarayları ve mabetleri. Türk Tarih Kurumu Yayınları.

Özgüç, T. (2002). Maşat Höyük, Kaška sınır bölgesinde bir idare merkezi. J. Wenzel. (Ed.), Hititler ve Hitit İmparatorluğu, 1000 tanrılı halk (s. 466-467). Kunst-und Ausstellungshalle.

Puchstein, O. (1984). Boghasköi, Die Bawwerke. Otto Zeller Verlag.

Schachner, A. (2010). MÖ 16. yy. Anadolu'sunda bir dönüm noktası. A. Süel. (Ed.), Uluslararası Hititoloji kongresi bildirileri, VII (2) (s. 661-692). T. C. Çorum Valiliği İl Kültür ve Turizm Müdürlüğü Yayınları.

Schachner, A. (2019). Hattuša, efsanevi Hitit Imparatorluğu'nun izinde. Homer Kitabevi.

Seeher, J. (2006a). Chronology in Hattusa: New approaches to an old problem. Byzas, 4, 197-214.

Seeher, J. (2006b). Hattuşa rehberi, Hitit başkentinde bir gün. Ege Yayınları.

Seeher, J. (2007). Hattuşa kerpiç kent suru, bir rekonstrüksiyon çalışması. Ege Yayınları.

Seeher, J. (2010). Wie viele turme braucht eine stadt überlegungen zu aufwand der Hethitischen befestigungsanlagen in der spöten bronze zeit. Byzas, 10, 27-43.

Seeher, J. (2013). Hitit Mimarlı̆̆ı, M. Doğan-Alparslan ve M. Alparslan (Eds.), Hititler bir Anadolu imparatorluğu (s. 314-337). Yapı Kredi Yayınları.

Seton-Williams, M. (1954). Cilician survey. Anatolian Studies, 4, 121-174. https://doi.org/10.2307/3642378

Sevin, V. (1995). Imikuşă̆ I. Türk Tarih Kurumu Basımevi.

Sir Gavaz, Ö. (2008, 28 Aralık). Hitit İmparatorluk Devri krallarından I. Šuppiluliuma Dönemi’nde Anadolu. Hitit Üniversitesi Sosyal Bilimler Enstitüsü Dergisi, 1, 21-39. https://hdl.handle.net/11491/5378

Süel, A. (2002). Ortaköy-Šapinuwa, KA Yener ve HA Hoffner Jr. (Eds.), Recent developments in Hittite archaeology and history (145-156). Eisenbrauns.

Süel, A. (2005). Ortaköy/Şapinuwa ören yerinde 2003 yılı çalışmaları. Kazı Sonuçları Toplantısı, 26 (2), 243 250. 
Çukurova Üniversitesi Sosyal Bilimler Enstitüsü Dergisi, Cilt 30, Sayı 2, 2021, Sayfa 28-46

Süel, A. \& Süel, M. (2002). 2000 yılı Ortaköy/Şapinuwa kazı çalışmaları. Kazı Sonuçları Toplantısı, 23 (1), 413 418.

Şenyurt, SY, Akçay, A. \& Kamış, Y. (2015). Ovaören 2013 yılı kazıları. Kazı Sonuçları Toplantısı, 36 (2), 101 120.

Ünal, A. (2003). Hititler Devrinde Anadolu II. Arkeoloji ve Sanat Yayınları.

Ünal, A. (2006, 1 Eylül). Eski Çağlar'da Çukurova'nın tarihi coğrafyası ve Kizzuwatna (Adana) Krallı̆̆ı'nın siyasi tarihi. Çukurova Üniversitesi Sosyal Bilimler Enstitü Dergisi, 15 (3), 15-44.

Ünal, A. (2016). Hititçe-Türkçe, Türkçe-Hititçe büyük sözlük. Bilgin Kültür Sanat Yayınları.

Ünal, A. (2018). Eski Anadolu siyasi tarihi, Eski Taş Devri'nden Hitit Devleti'nin yıkılışına kadar (MÖ 60.0001180). Bilgin Kültür Sanat Yayınları.

Vincenzi, T. (2008). Fortification walls, development and conformation of Anatolian 'Saw-Tooth Wall', 'Kastenmauer', 'Casematte', defence systems, and their building techniques in the bronze age. H. Kühne, RM Czichon ve FJ Kreppner (Eds.), Proceedings of the 4th archaeology of the Ancient Near East (s. 309-320). Harrassowitz Verlag.

Vincenzi, T. \& Rinaldi, P. (2007). The development of the military architecture ''Kastenmauer and 'Casematte', building techniques. Congresso internazionale di Ittitologia 5-9 Septembre 2005, Studi Micenei Ed Egeo-Anatolici, 49 (1), 217-226.

Von der Osten, HH (1937). The Alishar Hüyük season of 1930-1932, VIII (II). The University of Chicago Press.

Von der Osten, HH \& Schmidt, EF (1930). The Alishar Hüyük, season of 1927, VI (I). University of Chicago Press.

Woolley, L. (1955). Alalakh, an account of the excavations at Tell Atchana in Hatay. 1937-1949. Oxford University Press.

Woolley, CL (1921). Carchemish: Report on the excavations at Jerablus on behalf of the British Museum, part II: The town defences. Oxford University Press.

Yon, M. (2006). The city of Ugarit at Tell Ras Shamra. Eisenbrauns. https://doi.org/10.5325/j.ctv1bxh50p 